\title{
An Exploration of the Needling Depth in Acupuncture: The Safe Needling Depth and the Needling Depth of Clinical Efficacy
}

\author{
Jaung-Geng Lin, ${ }^{1}$ Pei-Chi Chou, ${ }^{1}$ and Heng-Yi Chu ${ }^{2}$ \\ ${ }^{1}$ School of Chinese Medicine, College of Chinese Medicine, China Medical University, No.91 Hsueh-Shih Road, Taichung 40402, Taiwan \\ ${ }^{2}$ Department of Rehabilitation, Tri-Servcie General Hospital, National Defense Medical Center, No. 325, Sec. 2,Chenggong Rd., \\ Neihu District, Taipei City 114, Taiwan
}

Correspondence should be addressed to Jaung-Geng Lin; jglin@mail.cmu.edu.tw and Pei-Chi Chou; b8830006@yahoo.com.tw

Received 23 February 2013; Accepted 23 May 2013

Academic Editor: Gerhard Litscher

Copyright (c) 2013 Jaung-Geng Lin et al. This is an open access article distributed under the Creative Commons Attribution License, which permits unrestricted use, distribution, and reproduction in any medium, provided the original work is properly cited.

\begin{abstract}
Objective. To explore the existing scientific information regarding safe needling depth of acupuncture points and the needling depth of clinical efficacy. Methods. We searched the PubMed, EMBASE, Cochrane, Allied and Complementary Medicine (AMED), The National Center for Complementary and Alternative Medicine (NCCAM), and China National Knowledge Infrastructure (CNKI) databases to identify relevant monographs and related references from 1991 to 2013. Chinese journals and theses/dissertations were hand searched. Results. 47 studies were recruited and divided into 6 groups by measuring tools, that is, MRI, in vivo evaluation, CT, ultrasound, dissected specimen of cadavers, and another group with clinical efficacy. Each research was analyzed for study design, definition of safe depth, and factors that would affect the measured depths. Depths of clinical efficacy were discussed from the perspective of de-qi and other clinical observations. Conclusions. Great inconsistency in depth of each point measured from different subject groups and tools exists. The definition of safe depth should be established through standardization. There is also lack of researches to compare the clinical efficacy. A well-designed clinical trial selecting proper measuring tools to decide the actual and advisable needling depth for each point, to avoid adverse effects or complications and promote optimal clinical efficacy, is a top priority.
\end{abstract}

\section{Introduction}

Acupuncture is an important part of traditional Chinese medicine and has been used for millennia of years to treat various clinical disorders based on ancient Chinese medicine theory. In recent one hundred years, acupuncture has become one of the most popular complementary and alternative therapies in the world. More than 100 million citizens in the European Union make use of complementary and alternative medicine (CAM) today. According to EICCAM files, the most commonly used CAM therapies in Europe are homeopathy, acupuncture, phytotherapy (i.e., herbal medicine), anthroposophic medicine, naturopathy, traditional Chinese herbal medicine, osteopathy, and chiropractic. In 2007, almost 4 out of 10 adults had used CAM therapy in the past 12 months. Results from the 2007 NHIS found that approximately one in nine children (11.8\%) used CAM therapy in the past 12 months. Between 2002 and 2007, increased use was seen among adults for acupuncture, deep breathing exercises, massage therapy, meditation, naturopathy, and yoga in the United States [1]. Given the fact of the rising incidence of chronic disease and stress-related illness in the West, along with an expanding awareness of the unwanted side effects of pharmaceutical treatment, there has been an increased utilization of acupuncture as a contemporary health care option [2]. Acupuncture is also practiced by about 40,000 physicians in Germany [3]. One of the three most commonly used methods of CAM is acupuncture in the United Kingdom [4]. There are $12 \%$ 19\% of individuals who had received acupuncture treatment in Europe [5]. A practitioner in UK reported that an estimated $10.0 \%$ of the UK population had received any CAM therapy (an estimated $6.5 \%$ had used one of the five main therapies: acupuncture, homeopathy, chiropractic, osteopathy, or herbal medicine) [6]. Acupuncture points are known as specific locations of the body that are needled during acupuncture treatment. Acupuncture 
points are located along meridians that have been defined by ancient writings of Chinese medicine since thousands of years ago. Traditionally, acupuncture points are localized using cun (or Tong Shen Cun) as proportional measurement. Ancient writings of acupuncture guidelines also refer to anatomical landmarks to help localize the needling position. Cuns usually used in the documents are as follows [7].

1.1. Proportional Bone (Skeletal) Cun (B-Cun). This method divides the height of the human body into 75 equal units. Using joints on the surface of the body as the primary landmarks, the length and width of every body part is measured by such proportions. The specific method is as follows: divide the height of the human body into 75 equal units and then estimate the length and width of a certain part of the body according to such units. One unit is equal to one cun.

1.2. Finger Cun (F-Cun). This method is based on the finger cun of the person to be measured for acupuncture point locations.

1.3. Fingerbreadth (F-Breadth). This method utilizes the width of the distal phalanx of the middle finger. This should be distinguished from the middle finger cun.

For example, the individual distance between nipples measures 8 cun, and the individual interscapular distance measures 6 cun. Several research reports have discussed the anatomy and physiology of acupuncture points in order to understand the therapeutic mechanism of acupuncture [39-42]. However, the actual mechanism by which acupuncture works remains controversial. The majority of these studies have been of an experimental nature or in vitro cadaver studies and lack discussions regarding needling depth. Acupuncture is generally considered to be a safe treatment. Most reported adverse events were minor complications such as needling pain, hematoma, nausea, vomiting, and fainting. Ancient Chinese literature and historical texts have also documented the adverse effects of acupuncture. There are two descriptions about the possible critical complications of acupuncture in chapter 60 of Huangdi Neijing: Spiritual Pivot. "Unskillful doctors may kill the patients instead of saving their lives." "Violation of the rules in performing needling therapy will kill the patients instead of saving their lives." Deep insertion at the acupuncture point Qupen (ST12) may cause dyspnea, cough, and even collapse of the lung. Complications in acupuncture practice may result from violations of sterile procedure and/or negligence of the practitioners. Serious side effects include cardiac tamponade $[43,44]$, pneumothorax [45, 46], endocarditis [47-49], hepatitis [50-52], chylothorax [53], and spinal cord injury $[50,54]$, and minor side effects include fainting $[55,56]$ and skin reactions $[57-$ 60]. Pneumothorax is the most common mechanical organ injury associated with acupuncture treatment [50, 61-64], and the related reports are from the United States [65-67], Canada [68], The Netherlands [69, 70], France [71], Norway [63], Portugal [72, 73], Denmark [74], Taiwan [75], Japan $[50,76]$, China $[45,77]$, and Hong Kong [78]. Based on the facts mentioned above, we understand that the safe needling depth for acupuncture therapy is a very important issue for clinical practice. However, there is only meager and confusing information about the safe needling depth in ancient classics of Chinese medicine and modern acupuncture textbooks. As some adverse events are preventable through preventive measures, there stands the need for urgent standardization regarding safe depth of acupuncture. We are also interested to learn if needling depth is correlated with the clinically observed therapeutic effects. In this paper, we provide a critical review of the current researches classified by the measuring tool on safe needling depth of acupuncture points as well as the therapeutic depth with clinical efficacy.

\section{Methods}

A comprehensive search of the literature that was published from 1991 to 2013 was undertaken using the following key words: acupuncture, acupoint, needling depth, safe depth, dangerous depth, de-qi, therapeutic effect/efficacy, and their synonyms. These terms were used to search the following databases: PubMed, EMBASE, Cochrane, Allied and Complementary Medicine (AME), The National Center for Complementary and Alternative Medicine (NCCAM), and China National Knowledge Infrastructure (CNKI) databases. Additional articles were also identified from the reference list of identified articles. Chinese journals, theses, and dissertations that we thought might be relevant to our study were hand searched. We excluded the animal studies.

\section{Results}

47 studies from 1991 to 2013 were recruited into the review. As there are not many researches specific for depth of acupuncture points, we tried to include as many articles as possible. Most of the studies were retrospective, nonrandomized clinical trials without control group. The characteristics of subjects, sample size, investigated acupuncture points with the associated body region/meridians, parameters used for comparison, related factors, results and suggestions/conclusions of the researches and related factors and the results and suggestions and conclusions of the researches were summarized in the following tables classified by their measuring tool, that is, magnetic resonance imaging (MRI), in vivo subjects evaluation, computed tomography scan (CT), ultrasound, and dissected specimens of cadavers, in Tables $1,2,3,4$, and 5. Table 6 depicts the investigations regarding clinical efficacy.

\subsection{The Safe Needling Depth}

3.1.1. Researches Using MRI Images for Measurement of the Depths of Acupuncture Points. Magnetic resonance imaging (MRI) is a medical imaging technique used in radiology to visualize internal structures of the body in detail. MRI provides better contrast between the different soft tissues of the body compared with other medical imaging techniques such as CT scans or X-rays which makes it the more 
TABLE 1: Summary of researches using MRI images for measurement of the depths of acupuncture points.

\begin{tabular}{|c|c|c|c|c|}
\hline Authors and year & $\begin{array}{l}\text { Subjects and } \\
\text { sample size }\end{array}$ & $\begin{array}{l}\text { Investigated acupuncture } \\
\text { points and their body } \\
\text { regions/meridians }\end{array}$ & $\begin{array}{l}\text { Parameters used in } \\
\text { comparison and } \\
\text { related factors }\end{array}$ & Results, suggestions, and conclusions \\
\hline Li $2011[8]$ & $\begin{array}{l}10 \text { male, } \\
10 \text { female }\end{array}$ & BL18 & $\begin{array}{l}\text { Gender, angle, side, } \\
\text { BL, BW, BMI, and } \\
\text { thumb cun }\end{array}$ & $\begin{array}{l}\text { (1) Male subjects had greater safe depth (mean } \\
25.1 \mathrm{~mm} \text { versus } 22.52 \mathrm{~mm} \text { ) } \\
\text { (2) Right side points had greater depths } \\
\text { (3) The perpendicular depths of right side } \\
\text { points correlated with BW, thumb cun; depths } \\
\text { of left side points correlated with BL, BW, BMI, } \\
\text { and thumb cun }\end{array}$ \\
\hline Fu $2011[9]$ & $\begin{array}{l}10 \text { male, } \\
10 \text { female }\end{array}$ & BL20 & $\begin{array}{l}\text { Gender, angle, side, } \\
\text { BL, BW, and BMI }\end{array}$ & $\begin{array}{l}\text { (1) No side differences } \\
\text { (2) With gender differences except when } \\
\text { needling angle is } 45 \text { degrees } \\
\text { (3) The safe depth did not correlate with BL, } \\
\text { BW, and BMI }\end{array}$ \\
\hline Chuan 2011 [10] & $\begin{array}{l}10 \text { male, } \\
10 \text { female }\end{array}$ & BL19 & $\begin{array}{c}\text { Gender, angle, BL, } \\
\text { BW, and BMI }\end{array}$ & $\begin{array}{l}\text { (1) The male subject had greater safe depth of } \\
\text { perpendicular needling } \\
\text { (2) If needled with the angles of } 30 \text { and } 45 \\
\text { degrees, no gender difference noted } \\
\text { (3) The depth may vary profoundly under } \\
\text { different angles, for example, } 2.02 \text { to } 4.0 \mathrm{~cm}\end{array}$ \\
\hline Yen 2011 [11] & $\begin{array}{l}10 \text { male, } \\
10 \text { female }\end{array}$ & BL17 & $\begin{array}{l}\text { Gender, angle, side, } \\
\text { BL, BW, and BMI }\end{array}$ & $\begin{array}{l}\text { (1) No obvious side difference } \\
\text { (2) The various needling angles and safe depth } \\
\text { did not correlate with BMI } \\
\text { (3) Mean depth of perpendicular depth in male } \\
\text { is } 4.11 \mathrm{~cm} \text { and } 3.16 \mathrm{~cm} \text { in females }\end{array}$ \\
\hline $\begin{array}{l}\text { Han } 2010[12] \text { and } \\
\text { Wen et al. } 2011[13]\end{array}$ & $\begin{array}{l}10 \text { male, } \\
10 \text { female }\end{array}$ & SP21 & $\begin{array}{l}\text { Gender, angle, BL, } \\
\text { BW, BMI, body cun }\end{array}$ & $\begin{array}{l}\text { (1) The safe needling angle should be about } 15 \\
\text { degrees towards the skin surface } \\
\text { (2) Difference in safe depth existed in various } \\
\text { needling angles } \\
\text { (3) The safe depth did not correlate with BL, } \\
\text { BW, BMI, thumb cun, and body cun }\end{array}$ \\
\hline Yu 2010 [14] & $\begin{array}{l}10 \text { male, } \\
10 \text { female }\end{array}$ & CV14, ST19 & $\begin{array}{l}\text { Gender, angle, BL, } \\
\text { BW, BMI, and body } \\
\text { cun }\end{array}$ & $\begin{array}{l}\text { (1) No gender differences in both points } \\
\text { (2) the safe depth of CV14 did not correlate } \\
\text { with BL, BW, BMI, or body cun } \\
\text { (3) the safe depth of ST19 correlated with BW, } \\
\text { BMI }\end{array}$ \\
\hline Ho 2010 [15] & $\begin{array}{l}10 \text { male, } \\
10 \text { female }\end{array}$ & ST18, GB24 & $\begin{array}{c}\text { Gender, angle, side, } \\
\text { and BMI }\end{array}$ & $\begin{array}{l}\text { (1) No side difference for ST18 } \\
\text { (2) Female subjects had greater depths } \\
\text { generally for ST18 } \\
\text { (3) Safe depths for ST18 and GB24 correlated } \\
\text { significantly with BMI }\end{array}$ \\
\hline Wu 2010 [16] & $\begin{array}{l}10 \text { male, } \\
10 \text { female }\end{array}$ & LR14 & $\begin{array}{c}\text { Gender, angle, side, } \\
\text { and BMI }\end{array}$ & $\begin{array}{l}\text { (1) Perpendicular needling depth was greater in } \\
\text { female subjects } \\
\text { (2) No gender difference } \\
\text { (3) Dangerous depth of LR14 correlated with } \\
\text { BMI significantly }\end{array}$ \\
\hline $\begin{array}{l}\text { Dong } 2010 \text { [17] and } \\
\text { Cheng and Dong } \\
2012[18]\end{array}$ & $\begin{array}{l}10 \text { male, } \\
10 \text { female }\end{array}$ & CV15, CV13 & $\begin{array}{l}\text { Gender, angle, BL, } \\
\text { BW, BMI, and body } \\
\text { cun }\end{array}$ & $\begin{array}{l}\text { (1) The safe depth for CV15 ranged from } 16.99 \\
\text { to } 53.47 \mathrm{~mm} \text { with no gender difference } \\
\text { (2) The safe depth for CV13 ranged from } 17.25 \\
\text { to } 62.74 \mathrm{~mm} \text { with no gender difference } \\
\text { (3) The safe depth of both points did not } \\
\text { correlate with BL, BW, and body cun }\end{array}$ \\
\hline Wang 2009 [19] & $\begin{array}{l}11 \text { male, } \\
9 \text { female }\end{array}$ & BL10 & $\begin{array}{l}\text { Gender, side, angle, } \\
\text { BL, BW, neck girth, } \\
\text { and thumb cun }\end{array}$ & $\begin{array}{l}\text { (1) No side and angle differences noted in both } \\
\text { groups } \\
\text { (2) Male subjects had greater depth } \\
\text { (3) The safe depth did not correlate with any of } \\
\text { the parameters }\end{array}$ \\
\hline
\end{tabular}


TABle 1: Continued.

\begin{tabular}{|c|c|c|c|c|}
\hline Authors and year & $\begin{array}{l}\text { Subjects and } \\
\text { sample size }\end{array}$ & $\begin{array}{l}\text { Investigated acupuncture } \\
\text { points and their body } \\
\text { regions/meridians }\end{array}$ & $\begin{array}{l}\text { Parameters used in } \\
\text { comparison and } \\
\text { related factors }\end{array}$ & Results, suggestions, and conclusions \\
\hline Chang 2009 [20] & $\begin{array}{l}11 \text { male, } \\
9 \text { female }\end{array}$ & GB20 & $\begin{array}{l}\text { Gender, angle, BL, } \\
\text { BW, BMI, neck } \\
\text { girth, and head girth }\end{array}$ & $\begin{array}{l}\text { (1) The needling direction towards the nose tip } \\
\text { would be the safest way } \\
\text { (2) Mean safe depth in males ranged from } 35.25 \\
\text { to } 42.75 \text { mm while } 29.92 \text { to } 36.19 \text { in females } \\
\text { (3) Safe depth correlated with neck, head girth, } \\
\text { BW, and BMI, but needling angle did not }\end{array}$ \\
\hline Bai 2009 [21] & $\begin{array}{l}11 \text { male, } \\
9 \text { female }\end{array}$ & GV16 & $\begin{array}{l}\text { Gender, angle, BL, } \\
\text { BW, BMI, neck } \\
\text { girth, and thumb } \\
\text { cun }\end{array}$ & $\begin{array}{l}\text { (1) Male subjects had greater depth with } \\
\text { various needling angles } \\
\text { (2) Needling depth correlated positively with } \\
\text { BW, BMI, and neck girth } \\
\text { (3) Safe depth ranged } 27.08-45.55 \mathrm{~mm}\end{array}$ \\
\hline Wu 2009 [22] & $\begin{array}{l}11 \text { male, } \\
9 \text { female }\end{array}$ & BL1, ST1 & Gender & $\begin{array}{l}\text { (1) The safe depth was defined as the } 75 \% \text { of } \\
\text { dangerous depth } \\
\text { (2) Perpendicular needling depth for BL1 was } \\
4.14 \mathrm{~mm} \text { ( } 19.87 \mathrm{~mm} \text { if along the axis of eyeball) } \\
\text { and } 17.85 \text { for ST1 } \\
\text { (3) With gender differences }\end{array}$ \\
\hline Lu 2009 [23] & $\begin{array}{l}11 \text { male, } \\
9 \text { female }\end{array}$ & GV15 & $\begin{array}{l}\text { Gender, angle, side, } \\
\text { BL, BW, BMI, neck } \\
\text { girth, and thumb } \\
\text { cun }\end{array}$ & $\begin{array}{l}\text { (1) Perpendicular needling depth was greater in } \\
\text { males } \\
\text { (2) Oblique needling depth was greater in } \\
\text { females at an angle of around } 15 \text { degrees } \\
\text { (3) Depth in male subjects correlated with BL, } \\
\text { BW, and neck girth while depth in female } \\
\text { group correlated with none of those parameters }\end{array}$ \\
\hline
\end{tabular}

appropriate measuring tool detecting acupuncture points in specific body regions. Unlike CT scans or traditional X-rays, MRI does not use ionizing radiation. Table 1 summarizes 14 studies (composed of 16 papers) that met the search criteria. These studies investigated 17 various acupuncture points in the head, face, chest, abdomen, and back region. Factors that may affect the measured depth including gender, body length (BL), body weight (BW), right or left side points, needling angle, body mass index (BMI), neck girth, and cun (thumb or body cun) were used for comparison. The results do not reach unanimity and contradict each other. For example, male subjects had greater safe depth only in BL18, BL19, and GV16 [8, 10, 16, 19, 21, 23]. The perpendicular depths of right side points correlated with BW, thumb cun while the depths of left side points correlated with BL, BW, BMI, and thumb cun in BL18 [8]. Needling depth correlated positively with BW, BMI, and neck girth in ST18, GB24, LR14, GB20, GV16, and GV15 $[15,16,20,21,23]$. On the other hand, the safe depth did not correlate with BL, BW and BMI in BL20, BL17, SP21, CV14, ST19, CV13, and CV15 [9, 11-14, 17, 18].

3.1.2. Researches Using In Vivo Evaluation Methods in Real Subjects. We recruited 8 studies that met the search criteria and are summarized in Table 2. Under this category, two studies were specifically conducted to treat patients with low back pain [24] and intervertebral herniation of cervical spines [28]. We observed a significant correlation between the interscapular distance and the thickness of the soft tissue layer with the BMI at BL25, BL26. As a result, using proportional methods is relevant for the success of acupuncture therapy [24]. Association between nerve contact and de-qi was also discussed. The rate of median nerve penetrations by the acupuncture needle at P6 was surprisingly high, but these seemed to carry no risk of neurologic sequelae. De-qi at P6 did not depend on median nerve contact, nor did it prevent median nerve penetration which confirms the idea that acupuncture is a safe treatment method [25]. The definition of safe depth should be less than $70 \%$ of dangerous depth as suggested in most of the similar investigations [26, 27]. From the needling angle perspective, safe needling angle should be 10 degrees more than dangerous angle at 7 points from bladder meridian (1st side line) [27, 29]. The measured depth of GV14, all back bladder meridian points, and some chest points were greater than documents from ancient writings $[28,29]$. The depths of all back bladder meridian points and some chest points highly correlated with body thickness and Tong Shen Cun [29]. Points of female chest had greater depth than male. De-qi depth is related to therapeutic effect; however, no correlations between the de-qi depth and electric resistance of each point in the chest and back regions were revealed $[29,31]$.

3.1.3. Researches Using CT Scan Images for Measurement of the Depths of Acupuncture Points. One of the mainstreams of measuring acupuncture points is using images from CT scans (13 studies were recruited in this review). One study defined the T/S ratio (therapeutic depth over safety depth). The therapeutic depth was defined as the depth at which 
TABLE 2: Summary of researches using in vivo evaluation methods in real subjects.

\begin{tabular}{|c|c|c|c|c|}
\hline Authors and year & $\begin{array}{l}\text { Subjects and sample } \\
\text { size }\end{array}$ & $\begin{array}{l}\text { Investigated acupuncture } \\
\text { points and their body } \\
\text { regions/meridians }\end{array}$ & $\begin{array}{l}\text { Parameters used in } \\
\text { comparison and } \\
\text { related factors }\end{array}$ & Results, suggestions, and conclusions \\
\hline $\begin{array}{l}\text { Groenemeyer } \\
\text { et al. } 2009 \text { [24] }\end{array}$ & $\begin{array}{l}58 \text { patients with low } \\
\text { back pain }\end{array}$ & BL25, BL26 & BMI & $\begin{array}{l}\text { (1) An association between de-qi and needle } \\
\text { location existed } \\
\text { (2) The distance between BL25 and BL6 to the } \\
\text { vertebral line was } 3.49 \pm 0.58 \text { and } \\
3.32 \pm 0.53 \mathrm{~cm} \text {, respectively } \\
\text { (3) There was a significant correlation between } \\
\text { the interscapular distance and the thickness of } \\
\text { the soft tissue layer with the BMI at both } \\
\text { acupuncture points }\end{array}$ \\
\hline $\begin{array}{l}\text { Streitberger et al. } \\
2007 \text { [25] }\end{array}$ & $\begin{array}{l}50 \text { patients receiving } \\
\text { acupuncture } \\
\text { including PC6 } \\
\text { bilaterally ( } 97 \text { wrists) }\end{array}$ & PC6 & $\begin{array}{l}\text { Nerve penetrated } \\
\text { or contacted }\end{array}$ & $\begin{array}{l}\text { (1) Association between nerve contact and } \\
\text { de-qi was discussed. De-qi was elicited in } 85 \\
\text { cases. No association between the number of } \\
\text { nerve contacts and de-qi was found } \\
\text { (2) The mean distance from the needle tip to } \\
\text { the nerve was } 1.8 \mathrm{~mm} \text { (standard deviation } 2.2 \text {; } \\
\text { range } 0-11.3 \text { ). Nerve contacts were recorded in } \\
52 \text { cases, in } 14 \text { of which the nerve was } \\
\text { penetrated by the needle }\end{array}$ \\
\hline
\end{tabular}

\section{(1) No side difference} $\begin{array}{ll}\begin{array}{l}\text { Dong et al. } 2004 \\ \text { [26] }\end{array} & \begin{array}{l}32 \text { adults and } 10 \\ \text { cadavers }\end{array}\end{array}$
7 points from bladder meridian (2nd side line)
Rohrer index: $<1.2$, (2) Depths from in vivo CT images were $1.2-1.5$, and $>1.5$, greater than ones from cadavers side

(3) Safe depth should be less than $70 \%$ of dangerous depth

(1) No side difference

(2) Depths from in vivo CT images were Rohrer index: $<1.2$, $1.2-1.5$, and $>1.5$, side, and needling angles

7 points from bladder meridian (1st side line)

greater than ones from cadavers

(3) Safe depth should be less than $70 \%$ of dangerous depth

(4) Safe needling angle should be 10 degrees more than dangerous angle

(1) Depth ranges $36-75 \mathrm{~mm}$ with a mean of $54.6 \mathrm{~mm}$. The safe depth should be within

He et al. 2004 [28] 40 patients of HIVD of C spine

$\mathrm{BL}, \mathrm{BW}$, and $\mathrm{AW} \quad 36 \mathrm{~mm}$

(2) Measured depth was greater than documents from ancient writings

80 cadavers (including 30 newborns) and 240

Lin 1997 [29] adults for safety depth; 300 real subjects for de-qi depth

all back bladder meridian points and chest points
Gender, Tong Shen Cun, BL, BW

(normal, over- and underweight) DQ, and AW
(1) Depths were deeper as compared to ancient writings. The depths highly correlated with body thickness and Tong Shen Cun

(2) De-qi depth was related to therapeutic effect (3) De-qi depths of chest points were greater in females but not in back points

$\begin{array}{lll} & & \\ & & \\ \text { Lin and Wang } \quad 300 \text { adults } & \begin{array}{l}\text { Total of } 75 \text { acupoints in } \\ \text { head, neck, trunk and } \\ \text { lower limb }\end{array} & \begin{array}{l}\text { Gender, BW, and } \\ \text { DQ [30] }\end{array}\end{array}$

(1) Discussed de-qi depth but not safe depth

(2) Depth of de-qi was greater in males and people with greater body weight

(3) Depths in neck region were more superficial in trunk and limbs

(1) Overweight group had the greatest de-qi

Lin 1991 [31] $\quad 107$ adults

Acupoints in the chest and back of subjects receiving acupuncture therapy depth

Gender, BW

(normal, over- and (2) Points of female chest had greater depth underweight), $\mathrm{BL}$, than male and DQ
(3) No correlations between the de-qi depth and electric resistance of each point 
TABLE 3: Summary of researches using CT scan images for measurement of the depths of acupuncture points.

\begin{tabular}{|c|c|c|c|c|}
\hline Authors and year & $\begin{array}{l}\text { Subjects and } \\
\text { sample size }\end{array}$ & $\begin{array}{l}\text { Investigated acupuncture } \\
\text { points and their body } \\
\text { regions/meridians }\end{array}$ & $\begin{array}{l}\text { Parameters used in } \\
\text { comparison and } \\
\text { related factors }\end{array}$ & Results, suggestions, and conclusions \\
\hline Chen et al. 2009 [32] & $\begin{array}{l}204 \text { pediatric } \\
\text { patients aged } \\
7-15\end{array}$ & $\begin{array}{l}12 \text { abdominal acupuncture } \\
\text { points CV-3, CV-4, CV-6, } \\
\text { CV-10, CV-12, CV-14, } \\
\text { KI-12, ST-24, ST-25, SP-15 } \\
\text { LV-13, and LV-4 }\end{array}$ & $\begin{array}{l}\text { Gender, age, BW, and } \\
\text { waist girth }\end{array}$ & $\begin{array}{l}\text { (1) Using the therapeutic depth over safety } \\
\text { depth ratio (T/S ratio) as the indicator of } \\
\text { therapeutic depth } \\
\text { (2) No significant difference in the T/S ratio } \\
\text { between genders } \\
\text { (3) The T/S ratio of these } 12 \text { acupuncture points } \\
\text { ranged from } 0.67 \text { to } 0.88 \text { and increased } \\
\text { significantly with body weight, age, and waist } \\
\text { girth } \\
\text { (4) The therapeutic depth of abdominal } \\
\text { acupoints was closer to the safe depth in } \\
\text { overweight and older children aged } 7 \text { to } 15 \\
\text { (5) No significant difference between genders }\end{array}$ \\
\hline $\begin{array}{l}\text { Groenemeyer et al. } \\
2009[24]\end{array}$ & $\begin{array}{l}58 \text { patients } \\
\text { with low back } \\
\text { pain }\end{array}$ & BL25, BL26 & BMI & $\begin{array}{l}\text { (1) An association between de-qi and needle } \\
\text { location existed } \\
\text { (2) The distance between BL } 25 \text { and BL6 to the } \\
\text { vertebral line was } 3.49 \pm 0.58 \text { and } \\
3.32 \pm 0.53 \mathrm{~cm} \text {, respectively } \\
\text { (3) There was a significant correlation between } \\
\text { the interscapular distance and the thickness of } \\
\text { the soft tissue layer with the BMI at both } \\
\text { acupuncture points }\end{array}$ \\
\hline
\end{tabular}
acupuncture points

(1) The safe needling depth should be less than $75 \%$ of the dangerous depth

Yang et al. 2008 [33] 41 adults $\quad$ GV16 Rohrer index

(2) The safe depths of GV16 were different for persons of different somatotypes ranging 27.73-33.39 mm

(1) The safe depth of 12 acupoints significantly increased with age, body weight, and waist girth in pediatric patients aged 7-15

219 pediatric

Chen et al. 2008 [34] patients aged 7-15
12 acupoints along the conception vessel $(\mathrm{CV})$ : CV-2 to CV-7 and CV-9 to $\mathrm{CV}-14$
Gender, age, BW, and among different age and body weight groups waist girth
(3) The safe depths were 1.3-2.1 times deeper in the 12-15-year-old group than in the 7-9-year-old group and 1.7-3 times deeper in overweight children than in underweight children

(1) Right side points seemed to be deeper, especially in people with Rohrer index $<1$ (2) Safety depth should be within $75 \%$ of the measured distance in each group; that is, 34 , 25 , and $23 \mathrm{~mm}$

The safe depths (75\% of dangerous depths) were different for different somatotypes; for example, the needling depth for GV14 was $32.86 \pm 3.96 \mathrm{~mm}$ for the thin person group and $47.93 \pm 5.30 \mathrm{~mm}$ for the fat person group

(1) No side difference

(2) Depths from in vivo CT images were greater than ones from cadavers

(3) Safe depth should be less than $70 \%$ of dangerous depth 
TABLe 3: Continued.

\begin{tabular}{|c|c|c|c|c|}
\hline Authors and year & $\begin{array}{l}\text { Subjects and } \\
\text { sample size }\end{array}$ & $\begin{array}{l}\text { Investigated acupuncture } \\
\text { points and their body } \\
\text { regions/meridians }\end{array}$ & $\begin{array}{l}\text { Parameters used in } \\
\text { comparison and } \\
\text { related factors }\end{array}$ & Results, suggestions, and conclusions \\
\hline Li et al. 2004 [27] & $\begin{array}{l}32 \text { adults and } \\
10 \text { cadavers }\end{array}$ & $\begin{array}{l}7 \text { points from bladder } \\
\text { meridian (1st side line) }\end{array}$ & $\begin{array}{l}\text { Rohrer index: }<1.2 \text {, } \\
1.2-1.5 \text {, and }>1.5 \text {, side, } \\
\text { and needling angles }\end{array}$ & $\begin{array}{l}\text { (1) No side difference } \\
\text { (2) Depths from in vivo CT images were } \\
\text { greater than ones from cadavers } \\
\text { (3) Safe depth should be less than } 70 \% \text { of } \\
\text { dangerous depth } \\
\text { (4) Safe needling angle should be } 10 \text { degrees } \\
\text { more than dangerous angle }\end{array}$ \\
\hline
\end{tabular}

\begin{tabular}{|c|c|c|c|c|}
\hline Lin 1997 [29] & $\begin{array}{l}80 \text { cadavers } \\
\text { (including } 30 \\
\text { newborns) and } \\
240 \text { adults for } \\
\text { safety depth; } \\
300 \text { real } \\
\text { subjects for } \\
\text { de-qi depth }\end{array}$ & $\begin{array}{l}\text { All back bladder meridian } \\
\text { points and chest points }\end{array}$ & $\begin{array}{l}\text { Gender, Tong Shen } \\
\text { Cun, BL, BW } \\
\text { (normal, over- and } \\
\text { underweight) DQ, } \\
\text { and AW }\end{array}$ & $\begin{array}{l}\text { (1) Depths were deeper as compared to ancient } \\
\text { writings. The depths highly correlated with } \\
\text { body thickness and Tong Shen Cun } \\
\text { (2) De-qi depth was related to therapeutic effect } \\
\text { (3) De-qi depths of chest points were greater in } \\
\text { females but not in back points }\end{array}$ \\
\hline $\begin{array}{l}\text { Sheu and Lin } \\
1992 \text { [37] }\end{array}$ & 120 adults & $\begin{array}{l}28 \text { points in the chest } \\
\text { from conception vessel, } \\
\text { kidney meridian, stomach } \\
\text { meridian, pericardium } \\
\text { meridian, lung meridian, } \\
\text { spleen meridian, and } \\
\text { gallbladder meridian }\end{array}$ & $\begin{array}{l}\text { gender, BW (normal, } \\
\text { over- and } \\
\text { underweight), and BL }\end{array}$ & $\begin{array}{l}\text { (1) Significant differences in chest points within } \\
\text { the same sex existed } \\
\text { (2) For different body sizes, statistically } \\
\text { significant differences for each point appeared }\end{array}$ \\
\hline Lin et al. 1991 [38] & $\begin{array}{l}240 \text { adults (120 } \\
\text { in each group) }\end{array}$ & $\begin{array}{l}22 \text { points in the back; } 28 \\
\text { points in the chest }\end{array}$ & $\begin{array}{l}\text { Gender, BW (normal, } \\
\text { over- and } \\
\text { underweight), and BL }\end{array}$ & $\begin{array}{l}\text { (1) No gender differences on back loci } \\
\text { (2) Significant differences in each point with } \\
\text { different body sizes } \\
\text { (3) Female chest points had greater depths } \\
\text { (4) The results should be more accurate than } \\
\text { cadaver study }\end{array}$ \\
\hline
\end{tabular}

the needle is in the muscular layer of specific acupuncture point. Chen et al. suggested that the $\mathrm{T} / \mathrm{S}$ ratios were between 0.67 (SP-15) and 0.88 (CV-6, CV-10). The therapeutic depth of abdominal acupoints was closer to the safe depth in overweight and older children aged 7 to 15 [32]. As for the definition of safe needling depth, it should be less than $75 \%$ of the dangerous depth $[33,35,36]$, but there were two studies reported that it should be report that to be $70 \%$ of the dangerous depth $[26,27]$. Depths from in vivo CT images revealed that they were greater than the ones retrieved from cadavers $[26,27]$. According to the research of Lin, there were significant differences in chest points within the same sex, however, female chest points had greater depths [37]. In children subjects, the safe depths of studied points (CV-2 to CV-7 and CV-9 to CV-14) were 1.3-2.1 times deeper in the 12-15-year-old group than in the 7-9-year-old group and 1.73 times deeper in overweight children than in underweight children. The depths increased significantly with age and body size yet with large variations [34].

3.1.4. Researches Using Ultrasound Images for Measurement of the Depths of Acupuncture Points. We included 2 studies under this category. Lian suggested that needling depths of acupoints BL11 to BL21 ranged from $12-40 \mathrm{~mm}$ and not affected by age, body sizes, and disease types. Gender and side differences also existed, and depths measured were shorter compared to ancient writings [79]. Streitberger et al. found that there was no association between the number of nerve contacts and de-qi when needling at PC6, and the mean distance from the needle tip to the nerve was $1.8 \mathrm{~mm}$ (standard deviation 2.2; range $0-11.3$ ). The ultrasound has the advantage of acquiring real-time images; as a result, the authors were able to observe actual nerve contacts by the needle tip, and thus the possible complication of nerve penetration was recorded for analyses (leaving no neurological sequelae) [25].

3.1.5. Researches Using Dissected Specimens of Cadavers for Measurement of the Depths of Acupuncture Points. We included 21 investigations under this category. This is another measuring method used extensively in early investigations which continues to be valuable for certain points. A few studies defined the safe depth and dangerous depth for needling, respectively. For example, five studies suggested that the safe depth should be less than $70 \%$ of dangerous depth $[26,27,86,89,95,96]$. Yan et al. suggested that the safe depth of GV15, GV16, GB20, and BL1 should be $80 \%$ of the measured depth [97]. Li et al. defined the safe depths to be within $75 \%$ of the measured depths because they used in vivo CT images, which should be greater than the ones from cadavers [27]. In short, most of the authors chose $75 \%$ or $80 \%$ from their clinical experience rather than conclusive anatomical evidence. Consequently, there is no universal 
TABLE 4: Summary of researches using ultrasound images for measurement of the depths of acupuncture points.

\begin{tabular}{|c|c|c|c|c|}
\hline Authors and year & $\begin{array}{l}\text { Subjects and } \\
\text { sample size }\end{array}$ & $\begin{array}{l}\text { Investigated acupuncture } \\
\text { points and their body } \\
\text { regions/meridians }\end{array}$ & $\begin{array}{l}\text { Parameters used in } \\
\text { comparison and } \\
\text { related factors }\end{array}$ & Results, suggestions, and conclusions \\
\hline Lian 1995 [79] & 89 adults & $\begin{array}{l}\text { From BL11 to BL21 (11 } \\
\text { points) }\end{array}$ & $\begin{array}{l}\text { Gender, age, BL, BW, } \\
\text { disease type, side, and } \\
\text { AW }\end{array}$ & $\begin{array}{l}\text { (1) Depths ranged } 12-40 \mathrm{~mm} \\
\text { (2) Depth was not affected by age or body } \\
\text { sizes } \\
\text { (3) Points of male subjects and right side of } \\
\text { the body had greater depths } \\
\text { (4) Disease type did not affect depth } \\
\text { (5) Depths measured were shorter compared } \\
\text { to ancient writings }\end{array}$ \\
\hline $\begin{array}{l}\text { Streitberger et al. } \\
2007 \text { [25] }\end{array}$ & $\begin{array}{l}50 \text { patients } \\
\text { receiving } \\
\text { acupuncture } \\
\text { including PC6 } \\
\text { bilaterally ( } 97 \\
\text { wrists) }\end{array}$ & PC6 & $\begin{array}{l}\text { Nerve penetrated or } \\
\text { contacted DQ }\end{array}$ & $\begin{array}{l}\text { (1) Association between nerve contact and } \\
\text { de-qi was discussed. De-qi was elicited in } 85 \\
\text { cases. No association between the number of } \\
\text { nerve contacts and de-qi was found } \\
\text { (2) The mean distance from the needle tip to } \\
\text { the nerve was } 1.8 \mathrm{~mm} \text { (standard deviation } \\
2.2 \text {; range } 0-11.3 \text { ). Nerve contacts were } \\
\text { recorded in } 52 \text { cases, in } 14 \text { of which the } \\
\text { nerve was penetrated by the needle }\end{array}$ \\
\hline
\end{tabular}

definition of dangerous depth, safe depth, or therapeutic depth. Wang proposed that the needling depth of ST7 and SI18 revealed no side difference, and the mean inserting depths from skin surface to sphenopalatine ganglion are 49.9 and $46.6 \mathrm{~mm}$, respectively, which may change by different puncturing directions [81]. As for gender and side perspective, there was no gender difference in dangerous depth in SI14, ST12, BL1, L12, BL13, GV14, GV15, GV16, and GB20 and acupoints in back and lumbar regions [82, 84, 85, 95]. There was no side difference in dangerous depth in ST7, ST12, SI18, GV15, GV16, and GB20, 7 points from bladder meridian (2nd side line), 7 points from bladder meridian (1st side line), 28 acupoints in back and lumbar regions, and 23 chest points [26, 27, 81, 84, 95-97]. Details of each research are summarized in Table 5.

3.2. The Needling Depth of Clinical Efficacy. This section is composed of 11 researches. Lin had first investigated the needling depths of acupuncture points regarding de-qi in a series of researches since 1991 [29-31]. He proposed that de-qi depth was related to therapeutic effect. Depth of de-qi was greater in males and people with greater body weight except for chest points in females. He also found no correlations between the de-qi depth and electric resistance of the acupuncture points. Chen et al. also used the therapeutic depth over safety depth ratio (T/S ratio) as the indicator of therapeutic depth. There was no significant difference in the $\mathrm{T} / \mathrm{S}$ ratio between genders, and the T/S ratio of these 12 acupuncture points ranged from 0.67 to 0.88 and increased significantly with body weight, age, and waist girth [32]. Groenemeyer et al. suggested that an association between deqi and needle location exists [24]. However, Streitberger et al. found no association between the number of nerve contacts and de-qi [25]. The depth of needle penetration counted for the clinical efficacy of relief of muscle pain [102]. Deep puncturing at ST7 was more effective than routine puncturing, and the total effective rate in deep puncturing group is superior than that in shallow puncturing group [98]. Itoh et al. suggested that immediate pain relief in muscle group (deep insertion for $10 \mathrm{~mm}$ ) was better than that in skin group (insertion for $3 \mathrm{~mm}$ ) [102]. Deeper insertion also induced more dull sensations as compared to shallow insertions which induced more sharp sensations. In addition, needle rotation significantly increased the dull sensations [99]. Lu and Tang confirmed the various needling depths ranged from 2-12 $\mathrm{mm}$ as documented in Lingshu (Miraculous Pivot) used for treating irritable bowel syndrome of diarrhea [101].

\section{Discussion}

To our knowledge, this is the most comprehensive research to review all the studies regarding safe needling depth and clinical efficacy of acupuncture points. We tried to include researches as many as possible to provide a solid foundation for evidence based medicine in terms of advisable needling depth when performing acupuncture treatment. Evidence based medicine allows researchers or clinicians nowadays to ask a more extensive spectrum of miscellaneous research questions such as "Is acupuncture more effective than placebo?" or "Is CAM therapy along with wonted care more effective than wonted care alone?" These issues could be dealt with through appropriate study designs.

Studies of acupuncture safety indeed need special attention to needling depth issues. For example, the relationship between the effect of acupuncture analgesia and needling direction, angle, and depth has been optimized to enhance the analgesic effect as suggested by Fan et al. The result shows that all the 3 factors are the key influences. However, studies addressed the more specific correlation between needling depth, and issues aroused from safety or clinical efficacy are still far from enough [103]. 
TABLE 5: Summary of researches using dissected specimens of cadavers for measurement of the depths of acupuncture points.

\begin{tabular}{llll}
\hline Authors and year $\quad \begin{array}{l}\text { Subjects and sample } \\
\text { size }\end{array}$ & $\begin{array}{l}\text { Investigated acupuncture } \\
\text { points and their body } \\
\text { regions/meridians }\end{array}$ & $\begin{array}{l}\text { Parameters used in } \\
\text { comparison and } \\
\text { related factors }\end{array}$ & $\begin{array}{l}\text { Results, suggestions, and conclusions } \\
\text { (1) The acupuncture needle should not be } \\
\text { inserted deeply at PC6 in order to } \\
\text { minimise the risk of trauma } \\
\text { (2) It seemed likely that various kinds of } \\
\text { noninvasive stimulation at PC6 may be } \\
\text { similarly effective as needling } \\
\text { (3) Careful insertion of the needle with } \\
\text { respect to patients' sensations and better } \\
\text { anatomical knowledge of the forearm can } \\
\text { help to prevent unexpected needle } \\
\text { penetration of the median nerve or } \\
\text { persistent median artery }\end{array}$ \\
\hline
\end{tabular}

(1) No side difference

Wang et al. 2009 [81] 15 adult cadavers ST7, SI18 Side
$46.6 \mathrm{~mm}$

(1) No gender difference

(2) The mean dangerous depth for

Xie et al. 2007 [82] $\quad 46$ adult cadavers $\quad$ SI14 and GV14 Gender
perpendicular insertion was $60.60 \mathrm{~mm}$ for

(3) Suggested depth for perpendicular needling of SI14 and GV14 was within $42 \mathrm{~mm}$ in adult

(1) The needle not only easily injuried the upper pleural cavity but also damaged the

\begin{abstract}
Chen et al. 2007 [83] 46 cadavers
CV22, ST11
\end{abstract}

Xie et al. 2006 [84] 46 cadavers

ST12

Gender, side

Gender, angles of

Xie et al. 2006 [85] 46 cadavers $\quad$ BL12, BL13

Xie et al. $2006[85] \quad 46$ cadavers BL12, BL13
$(15,20,25,30$, and needle insertion 40 degrees) big blood vessel, the vagus nerve in the mediastinum and the cervical root (2) The safety depth of ST11 ranged 23.7-52.8 mm

(1) No gender or side difference

(2) The mean dangerous depth of male was $34.97 \mathrm{~mm}$ and female $31.41 \mathrm{~mm}$

(3) The depth for perpendicular needling of SI12 is within $22.50 \mathrm{~mm}$

(1) The mean dangerous depth for perpendicular insertion was $49.51 \mathrm{~mm}$ of BL12 and $44.88 \mathrm{~mm}$ of BL13

(2) It was safe for oblique insertion toward the medial of chest in an angle exceeding 20 degrees

(3) No gender difference

(1) The mean depth between the skin and the anterior ethmoidal artery was $18.25 \pm 4.45 \mathrm{~mm}$, with an angle of $12.5 \pm 5.5$ degrees

Xu et al. 2006 [86] 48 adult cadavers BL1 (2) The depth from the skin to the optic nerve tunnel frontal point was $43.37 \pm 7.84 \mathrm{~mm}$ (3) Needling depth should not exceed $30.36 \mathrm{~mm}$ (70\% of measured depth) to avoid injury of the optic nerve

(1) Average depth was $2.22 \mathrm{~cm}$

(2) Maximal depth was $4.42 \mathrm{~cm}$ if needled obliquely

(3) Safe depth was generally less than $5 \mathrm{~cm}$ 
TABLE 5: Continued.

\begin{tabular}{llll}
\hline Authors and year & $\begin{array}{l}\text { Subjects and sample } \\
\text { size }\end{array}$ & $\begin{array}{l}\text { Investigated acupuncture } \\
\text { points and their body } \\
\text { regions/meridians }\end{array}$ & $\begin{array}{l}\text { Parameters used in } \\
\text { comparison and } \\
\text { related factors }\end{array}$
\end{tabular}$\quad$ Results, suggestions, and conclusions

(1) Risk of pleural injury may existed when inserting needle perpendicularly in these

Chen et al. 2006 [88] 46 cadavers

CV22, ST11, ST12, GB21, EX-B1, and BL11 points

(2) Divergence existed in observed needling depths such as $22.5-61.3 \mathrm{~mm}$ for ST12

(1) No side difference

Dong et al. 2004 [26] 32 adults and $10 \quad 7$ points from bladder cadavers meridian (2nd side line)
Rohrer index: $<1.2$, $1.2-1.5$, and $>1.5$, side
(2) Depths from in vivo CT images were greater than ones from cadavers

(3) Safe depth should be less than $70 \%$ of dangerous depth

(1) No side difference

(2) Depths from in vivo CT images were Rohrer index: $<1.2$, $1.2-1.5$, and $>1.5$, side, and needling angles

points from blad cadavers

greater than ones from cadavers

(3) Safe depth should be less than $70 \%$ of dangerous depth

(4) Safe needling angle should be 10 degrees more than dangerous angle

(1) Safe depth should be less than $70 \%$ of dangerous depth

Yan et al. 2004 [89] 51 cadavers

74 points from neck, chest, back, and abdomen
Angles of insertion

(2) Needling angles were suggested such as 65 degrees rather than perpendicular insertion for points in the bladder meridian

(1) The dangerous depth of most abdominal points were similar and within 11-17 mm

(2) KI11 had the greatest depth up to $25 \mathrm{~mm}$ (to the urinary bladder) but with divergence in standard error

(1) The mean dangerous depths for perpendicular insertion downward was

Zhang et al. 2001 [91] 57 cadavers

ST12

$-$

$38.34 \mathrm{~mm}$

(2) Safety depth was within $26.83 \mathrm{~mm}$ (70\% of the dangerous depth)

The depth ranged $4.2-5.75 \mathrm{~cm}$ in different lumbar levels with greater depths in lower lumbar levels

(1) Safe depth (from skin to tibial nerve): $15 \mathrm{~mm}$ for left side and $16 \mathrm{~mm}$ for right side, less than the depth from current used textbook

(2) Depth from skin to deep vein: $35 \mathrm{~mm}$ Safe depth of GV15 (42.46-55.86 mm) and GV16 (43.46-57.42 $\mathrm{mm}$ ) correlated with thumb Tong Shen Cun

(1) No side difference in dangerous depth except BL17, BL18 for male and BL17 for female

Total of 28 acupoints in back and lumbar region
Gender, side
(2) Points of bladder meridian closer to the spine had greater depths. Divergence existed between points (3) There was no gender/side difference 
TABLE 5: Continued.

\begin{tabular}{|c|c|c|c|c|}
\hline Authors and year & $\begin{array}{l}\text { Subjects and sample } \\
\text { size }\end{array}$ & $\begin{array}{l}\text { Investigated acupuncture } \\
\text { points and their body } \\
\text { regions/meridians }\end{array}$ & $\begin{array}{l}\text { Parameters used in } \\
\text { comparison and } \\
\text { related factors }\end{array}$ & Results, suggestions, and conclusions \\
\hline Zhang et al. 1998 [96] & 51 cadavers & 23 chest points & Gender, side & $\begin{array}{l}\text { (1) The average dangerous depths of } 23 \\
\text { chest acupoints were obtained. KI } 27 \text { had } \\
\text { the greatest dangerous depth up to } 26 \mathrm{~mm} \text {. } \\
\text { Others ranged from } 11.87 \text { to } 17.64 \mathrm{~mm} \\
\text { (2) Divergence existed between points } \\
\text { (3) There was no gender/side difference } \\
\text { (4) Safe depth should be less than } 70 \% \text { of } \\
\text { dangerous depth }\end{array}$ \\
\hline Lin 1997 [29] & $\begin{array}{l}80 \text { cadavers } \\
\text { (including } 30 \\
\text { newborns) and } 240 \\
\text { adults for safety } \\
\text { depth; } 300 \text { real } \\
\text { subjects for de-qi } \\
\text { depth }\end{array}$ & $\begin{array}{l}\text { All back bladder meridian } \\
\text { points and chest points }\end{array}$ & $\begin{array}{l}\text { Gender, Tong Shen } \\
\text { Cun, BL, BW } \\
\text { (normal, over- and } \\
\text { underweight) DQ, } \\
\text { and AW }\end{array}$ & $\begin{array}{l}\text { (1) Depths were deeper as compared to } \\
\text { ancient writings. The depths highly } \\
\text { correlated with body thickness and Tong } \\
\text { Shen Cun } \\
\text { (2) De-qi depth was related to therapeutic } \\
\text { effect } \\
\text { (3) De-qi depths of chest points were } \\
\text { greater in females but not in back points }\end{array}$ \\
\hline Yan et al. 1996 [97] & 51 cadavers & $\begin{array}{l}\text { GV16, GV15, GB20, and } \\
\text { BL1 }\end{array}$ & Gender, side & $\begin{array}{l}\text { (1) The safe depths ( } 80 \% \text { of the measured } \\
\text { depth) were GV16: } 40.08 \mathrm{~mm} \text {, GV15: } \\
38.10 \mathrm{~mm} \text {, GB20: } 39.77 \mathrm{~mm} \text {, and BL1: } \\
34.25 \mathrm{~mm} \\
\text { (2) No gender or side difference }\end{array}$ \\
\hline
\end{tabular}

Most of the researches included in this review are retrospective in nature along with small sample size and lack randomization and control group, and most of the researches did not apply the WHO Standard Acupuncture Point Locations, let alone that they employed different measuring tools. Therefore, we observed the great inconsistency of measured needling depth among different subject groups. The inconsistency may also result from the following variables not strictly controlled in most of the researches:

(1) the difference in ethnicity;

(2) the age of the subjects;

(3) the gender difference;

(4) the subjects were not all divided in to groups by a more specific index for body sizes such as BMI;

(5) most of the subjects were not grouped by their underlying condition, that is, healthy subjects or with specific medical conditions;

(6) the definitions of safe needling depth, dangerous needling depth were obscure including the needling angle of specific acupuncture point and which side of the body the points were located.

All these facts lead to discrepancy in the safe depth measurements. For example, the suggested safe depths for GV16 are 27.05-45.55 mm (using MRI images) [21], 27.73-33.39 mm (using CT images) [33], $40.08 \mathrm{~mm}$ (using dissected specimens) [97], and 43.46-57.42 $\mathrm{mm}$ (using dissected specimens) [94].

In order to lift the level of acupuncture safety, it is necessary to utilize modern imaging technology to explore the safe depth of each acupuncture point all over the human body. We should take the regional and anatomical properties of different groups of points into consideration when deciding the measuring tools. For example, MRI imaging is very suitable for the acupuncture points in the abdominal and back regions due to the excellent ability to obtain soft tissue details while CT scan images are extremely helpful when detecting chest points. Ultrasound is a convenient tool which can obtain real-time images when trying to observe the clinical efficacy simultaneously, especially applied in vivo subjects. Using direct specimen dissections of cadavers is another measuring method. After frozen, anticorrosive, positioning, and dyeing process, the original elasticity and properties of the corpse tissues have been lost; the concerns which may arise from this kind of study are that specimens are drier and smaller than living human tissues. This may lead to possible inconsistency in measured needling depth. For example, Li et al. [27] and Dong et al. [26] compared the depths of 7 points from bladder meridian and found that depths measured via in vivo CT images were greater than ones from dissections of cadavers.

The measurement of needling depth involves the detection of soft tissue mostly. Different measurement methods often result in possible discrepancies due to the characteristic of each measuring tool. For example, Fiirgaard et al. suggested that MRI is superior in estimating the volume of acoustic neuroma than CT scan and with less inter-examiner difference [104]. MRI was reported to be better in identifying suspected disease of the brain and cervical spinal cord [105]. The sensitivity for detecting bony osteolytic lesions was $51.7 \%$ for radiography, $74.7 \%$ for computed tomography, and $95.4 \%$ for magnetic resonance imaging as reported by Walde et al. [106]. 
TABLE 6: Summary of researches involving the correlation between therapeutic effect and needling depth.

\begin{tabular}{ll}
\hline Authors and year & $\begin{array}{l}\text { Subjects and sample } \\
\text { size }\end{array}$ \\
\hline He et al. 2012 [98] & $\begin{array}{l}\text { (3) subjects with } \\
\text { trigeminal neuralgia } \\
\text { shallow puncturing } \\
\text { group) }\end{array}$ \\
\hline
\end{tabular}
$\begin{array}{ll}\text { Investigated acupuncture } & \text { Parameters used in } \\ \text { points and their body } & \text { comparison and } \\ \text { regions/meridians } & \text { related factors }\end{array}$

Results, suggestions, and conclusions

(1) The total effective rate was $93.8 \%$ in deep Pain index (VAS), puncturing group, superior to that of $87.1 \%$ traditional Chinese in shallow puncturing group trigeminal neuralgia (32 in deep and 31 in group)
ST7, LI4, LV3, BL2, ST2, and Jiacheng Jiang medicine symptoms index, and clinical therapeutic effect
(2) No adverse reaction was observed in both groups

(3) Deep puncturing at ST7 to the depth of sphenopalatine ganglion was more effective than routine puncturing

(1) Pilot study using ultrasound tried to explore the correlation between de-qi sensation and needling depth/needle manipulation

(2) Shallower insertion induced more sharp sensations

(3) Deeper insertion induced more dull sensations

(4) Needle rotation significantly increased the dull sensations

(1) A pilot, open, randomized, and Bilateral insertion single-blinded controlled trial to assess the at ST36 at the depth of $12 \mathrm{~mm}$, feasibility of acupuncture treatment for infantile colic reduction of crying (2) No adverse events were reported time from baseline (3) Acupuncture group had more reduction of crying time from baseline

(1) Various needling depths ranged 2-12 $\mathrm{mm}$ as documented in Lingshu (Miraculous Pivot)

(2) After treatment, there was significant change in IBS-SSS, and the effective rate may reach $90.5 \%$

(3) The longer the session of treatment was, the better the efficacy was obtained

(4) Confirmed the needling depth recorded in Lingshu

(1) Randomized controlled trial

(2) Immediate pain relief in muscle group (depth of $10 \mathrm{~mm}$ insertion into extensor digital muscle) which was better than skin group (depth of $3 \mathrm{~mm}$ )

(3) Acupuncture stimulation of muscle increases the PPT and EPT of fascia. The depth of needle penetration was important for the relief of muscle pain

(1) Using the therapeutic depth over safety depth ratio ( $\mathrm{T} / \mathrm{S}$ ratio) as the indicator of therapeutic depth

(2) No significant difference in the T/S ratio between genders

(3) The T/S ratio of these 12 acupuncture 12 abdominal acupuncture points CV-3, CV-4, CV-6, Chen et al. 2009 [32] $\begin{aligned} & 204 \text { pediatric patients } \\ & \text { aged 7-15 }\end{aligned}$ CV-10, CV-12, CV-14, KI-12, ST-24, ST-25, SP-15 and waist girth LV-13, and LV-4 points ranged from 0.67 to 0.88 and increased significantly with body weight, age, and waist girth

(4) The therapeutic depth of abdominal acupoints was closer to the safe depth in overweight and older children aged 7 to 15 (5) No significant difference between genders 
TABLE 6: Continued.

\begin{tabular}{lllll}
\hline Authors and year & $\begin{array}{l}\text { Subjects and sample } \\
\text { size }\end{array}$ & $\begin{array}{l}\text { Investigated acupuncture } \\
\text { points and their body } \\
\text { regions/meridians }\end{array}$ & $\begin{array}{l}\text { Parameters used in } \\
\text { comparison and } \\
\text { related factors }\end{array}$ & Results, suggestions, and conclusions \\
\hline & & & $\begin{array}{l}\text { (1) An association between de-qi and needle } \\
\text { location existed } \\
\text { (2) The distance between BL25 and BL6 to } \\
\text { the vertebral line is } 3.49 \pm 0.58 \text { and }\end{array}$ \\
$\begin{array}{llll}\text { Groenemeyer et al. } \\
2009[24]\end{array}$ & $\begin{array}{l}58 \text { patients with low } \\
\text { back pain }\end{array}$ & BL25, BL26 & BMI & $\begin{array}{l}3.32 \pm 0.53 \mathrm{~cm} \text {, respectively } \\
\text { (3) The was a significant correlation } \\
\text { between the interscapular distance and the } \\
\text { thickness of the soft tissue layer with the } \\
\text { BMI at both acupuncture points }\end{array}$ \\
\hline
\end{tabular}
BMI at both acupuncture points

(1) Association between nerve contact and de-qi was discussed. De-qi was elicited in 85

$\begin{array}{llll} & 50 \text { patients receiving } & & \text { Nerve penetrated } \\ \text { Streitberger et al. } & \begin{array}{l}\text { acupuncture } \\ \text { including PC6 } \\ \text { bilaterally (97 wrists) }\end{array} & \text { PC6 } & \text { or contacted }\end{array}$
cases. No association between the number of nerve contacts and de-qi was found

(2) The mean distance from the needle tip to the nerve was $1.8 \mathrm{~mm}$ (standard deviation 2.2; range 0-11.3). Nerve contacts were recorded in 52 cases, in 14 of which the nerve was penetrated by the needle

\begin{tabular}{|c|c|c|c|c|}
\hline Lin 1997 [29] & $\begin{array}{l}80 \text { cadavers } \\
\text { (including } 30 \\
\text { newborns) and } 240 \\
\text { adults for safety } \\
\text { depth; } 300 \text { real } \\
\text { subjects for de-qi } \\
\text { depth }\end{array}$ & $\begin{array}{l}\text { All back bladder meridian } \\
\text { points and chest points }\end{array}$ & $\begin{array}{l}\text { Gender, Tong Shen } \\
\text { Cun, BL, BW } \\
\text { (normal, over and } \\
\text { under-weight) DQ, } \\
\text { and AW }\end{array}$ & $\begin{array}{l}\text { (1) Depths were deeper as compared to } \\
\text { ancient writings. The depths highly } \\
\text { correlated with body thickness and Tong } \\
\text { Shen Cun } \\
\text { (2) De-qi depth was related to therapeutic } \\
\text { effect } \\
\text { (3) De-qi depths of chest points were greater } \\
\text { in females but not in back points }\end{array}$ \\
\hline $\begin{array}{l}\text { Lin and Wang } 1994 \\
\text { [30] }\end{array}$ & 300 adults & $\begin{array}{l}\text { Total of } 75 \text { acupoints in } \\
\text { head, neck, trunk, and } \\
\text { lower limb }\end{array}$ & $\begin{array}{l}\text { Gender, BW, and } \\
\text { DQ }\end{array}$ & $\begin{array}{l}\text { (1) Discussed de-qi depth but not safe depth } \\
\text { (2) Depth of de-qi was greater in males and } \\
\text { people with greater body weight } \\
\text { (3) Depths in neck region were more } \\
\text { superficial in trunk and limbs }\end{array}$ \\
\hline Lin 1991 [31] & 107 adults & $\begin{array}{l}\text { Acupoints in the chest and } \\
\text { back of subjects receiving } \\
\text { acupuncture therapy }\end{array}$ & $\begin{array}{l}\text { Gender, BW } \\
\text { (normal, over- and } \\
\text { underweight), BL, } \\
\text { and DQ }\end{array}$ & $\begin{array}{l}\text { (1) Overweight group had the greatest de-qi } \\
\text { depth } \\
\text { (2) Points of female chest had greater depth } \\
\text { than male } \\
\text { (3) No correlations between the de-qi depth } \\
\text { and electric resistance of each point }\end{array}$ \\
\hline
\end{tabular}

Yet MRI scanogram is slightly less accurate compared with radiographic scanogram in detecting limb length differences [107].

In addition, we also found several studies discussing the divergence among different measuring tools when investigating various body tissues including adipose volume (visceral or subcutaneous), muscle thickness, bone loss, and cartilage thickness. All these body tissues are relevant to the measurement of acupuncture points. However, the results indicated that no single measuring method would be more suitable than the other one (MRI, CT, and ultrasound). There was no significant difference between CT and MRI in the measurement of adipose tissue, glenoid bone loss, hip cartilage thickness, pheochromocytoma and in vivo skeletal muscle. Ultrasound was as good as MRI in the evaluation of supraspinatus and deltoid muscle with high correlation coefficients (0.96 and 0.97 , resp.). MRI was also proved to be as precise as direct cadaver measurement to evaluate adipose tissue.

There was no difference using either ultrasound or CT for the measurement of visceral fat volume. While ultrasound was as good as CT and MRI to assess intra-abdominal adipose tissue [108-117].

Some authors compared the results of MRI/CT imaging with cadavers in measuring adipose tissue [110], skeletal muscle [115], and hyaline cartilage thickness of hips [117] and found that both MRI and CT can serve as a good reference tool in the measurement. But Stevens-Simon et al. reported that the results of their study do not support the validity of ultrasound measurement of visceral adiposity as a measure of central adiposity in postpartum teenagers [118].

Consequently, the results in terms of measuring specific body tissues using different measuring methods are ambiguous and sometimes conflicting with each other. This fact may 
TABLE 7: Mean values for needling depths of acupoints in the chest in different-sized male subjects.

\begin{tabular}{|c|c|c|c|c|}
\hline Acupoints & $\begin{array}{l}\text { Overweight adults } \\
\text { Mean } \pm 95 \% \text { C.I. }\end{array}$ & $\begin{array}{c}\text { Normal adults } \\
\text { Mean } \pm 95 \% \text { C.I. }\end{array}$ & $\begin{array}{c}\text { Underweight adults } \\
\text { Mean } \pm 95 \% \text { C.I. }\end{array}$ & $F$ \\
\hline Tiantu (CV22) & $3.94 \pm 0.19$ & $2.87 \pm 0.26$ & $2.34 \pm 0.65$ & $19.61^{*}$ \\
\hline Xuanji (CV21) & $0.94 \pm 0.11$ & $0.64 \pm 0.10$ & $2.30 \pm 0.10$ & $38.22^{*}$ \\
\hline Huagai (CV20) & $0.89 \pm 0.11$ & $0.057 \pm 0.10$ & $0.25 \pm 0.10$ & $39.46^{*}$ \\
\hline Zigong (CV19) & $0.89 \pm 0.11$ & $0.60 \pm 0.10$ & $0.29 \pm 0.10$ & $35.79^{*}$ \\
\hline Yutang (CV18) & $0.88 \pm 0.14$ & $0.53 \pm 0.10$ & $0.28 \pm 0.09$ & $31.32^{*}$ \\
\hline Danzhong (CV17) & $0.86 \pm 0.11$ & $0.52 \pm 0.11$ & $0.25 \pm 0.09$ & $36.96^{*}$ \\
\hline Zhongting (CV16) & $0.95 \pm 0.14$ & $0.56 \pm 0.13$ & $0.34 \pm 0.11$ & $25.57^{*}$ \\
\hline Shufu (KI27) & $4.19 \pm 0.46$ & $3.29 \pm 0.48$ & $2.32 \pm 0.49$ & $16.20^{*}$ \\
\hline Yuzhong (KI26) & $2.98 \pm 0.27$ & $2.20 \pm 0.25$ & $1.50 \pm 0.27$ & $34.18^{*}$ \\
\hline Shencang (KI25) & $2.59 \pm 0.21$ & $2.00 \pm 0.21$ & $1.26 \pm 0.22$ & $42.93^{*}$ \\
\hline Lingxu (KI24) & $2.56 \pm 0.17$ & $2.13 \pm 0.23$ & $1.49 \pm 0.19$ & $32.09^{*}$ \\
\hline Shenfeng (KI23) & $2.47 \pm 0.17$ & $1.96 \pm 0.17$ & $1.44 \pm 0.17$ & $40.78^{*}$ \\
\hline Bulang (KI22) & $2.33 \pm 0.15$ & $1.95 \pm 0.17$ & $1.46 \pm 0.15$ & $33.64^{*}$ \\
\hline Qihu (ST13) & $5.24 \pm 0.48$ & $4.15 \pm 0.55$ & $2.88 \pm 0.47$ & $23.71^{*}$ \\
\hline Kufang (ST14) & $3.82 \pm 0.36$ & $3.10 \pm 0.31$ & $2.02 \pm 0.29$ & $32.21^{*}$ \\
\hline Wuyi (ST15) & $3.11 \pm 0.27$ & $2.64 \pm 0.52$ & $1.38 \pm 0.17$ & $26.51^{*}$ \\
\hline Yingchuang (ST16) & $2.78 \pm 0.21$ & $2.35 \pm 0.53$ & $1.33 \pm 0.22$ & $19.52^{*}$ \\
\hline Ruzhong (ST17) & $2.59 \pm 0.19$ & $2.07 \pm 0.38$ & $1.23 \pm 0.20$ & $27.28^{*}$ \\
\hline Rugen (ST18) & $2.27 \pm 0.16$ & $1.78 \pm 0.22$ & $1.19 \pm 0.20$ & $33.89^{*}$ \\
\hline Tianchi (PC1) & $2.64 \pm 0.21$ & $2.25 \pm 0.72$ & $1.18 \pm 0.21$ & $11.97^{*}$ \\
\hline Yunmen (LU1) & $6.73 \pm 0.55$ & $5.14 \pm 0.57$ & $3.26 \pm 0.79$ & $32.78^{*}$ \\
\hline Zhongfu (LU2) & $5.05 \pm 0.62$ & $3.69 \pm 0.47$ & $2.20 \pm 0.70$ & $24.06^{*}$ \\
\hline Zhourong (SP20) & $3.71 \pm 0.50$ & $2.70 \pm 0.35$ & $1.68 \pm 0.51$ & $21.06^{*}$ \\
\hline Xiongxiang (SP19) & $3.15 \pm 0.37$ & $2.26 \pm 0.23$ & $1.53 \pm 0.43$ & $23.38^{*}$ \\
\hline Tianxi (SP18) & $2.88 \pm 0.29$ & $2.05 \pm 0.25$ & $1.32 \pm 0.19$ & $40.68^{*}$ \\
\hline Shidou (SP17) & $2.61 \pm 0.21$ & $1.91 \pm 0.22$ & $1.28 \pm 0.18$ & $45.01^{*}$ \\
\hline Zhejin (GB23) & $3.48 \pm 0.39$ & $2.43 \pm 0.26$ & $1.73 \pm 0.37$ & $28.00^{*}$ \\
\hline Yuanye (GB22) & $4.52 \pm 0.41$ & $3.07 \pm 0.34$ & $2.20 \pm 0.33$ & $43.58^{*}$ \\
\hline
\end{tabular}

$X$ : mean depth; units are provided in centimeters.

$X \pm 1.96$ SD: $95 \%$ confidence interval.

${ }^{*} P<0.01 ; F$ is the statistic for one-way ANOVA.

The definitions for "Overweight adults," "Normal adults," and "Underweight adults" are following the guidance of the Department of Health, Taiwan: "The suggested ideal body weight of Taiwanese people." As such, readers from outside Taiwan should bear in mind that ideal body weights differ between countries. The specified needling depths in the table are a suggested guide only.

partially explain the inconsistency of needling depth of each acupuncture point as reviewed in our study.

Some authors discussed the interobserver reliability as well. Botser et al. thought that CT was found to have higher interobserver reliability than MRI when deciding the degree of femoral anteversion [119]. MRI was again found to have less interexaminer difference in calculating the soft tissue volume [104]. Both studies pointed out that some of the measuring errors may come from the man-made technical faults.

As a result, it is very difficult to obtain a general conclusion regarding safe needling depth using these results; future researches are warranted which will be discussed later in the paper.

Some theses about using MRI for safe needling depth detection we included in this study seem to have the same sample population (number, sex ratio, age, and BMI are consistent with each other) which may result in bias in the interpretation of study results. In addition, the sample size is limited to 20 subjects which lack the power for further analysis of gender, age, and body size differences.

From the review, we learn that many factors may influence the measurement of needling depth. They include gender, age, body size (such as body length, body weight, waist girth, and BMI), which side of the body, angle of needling, and so forth. Chou et al. have reviewed part of the researches previously [120]. Among these factors, body size is always considered the most significant one which complies with our general understanding that subjects with greater body size would have greater measured depth in most of the acupuncture points. However, anatomical and structural difference exists in different human body regions when we take account of the factor like BMI.

The measured depth in body region with frequent accumulation of fat would be highly correlated with BMI. BMI 
TABLE 8: Mean values for needling depths of acupoints in the chest in different-sized female subjects.

\begin{tabular}{|c|c|c|c|c|}
\hline Acupoints & $\begin{array}{l}\text { Overweight adults } \\
\text { Mean } \pm 95 \% \text { C.I. }\end{array}$ & $\begin{array}{c}\text { Normal adults } \\
\text { Mean } \pm 95 \% \text { C.I. }\end{array}$ & $\begin{array}{c}\text { Underweight adults } \\
\text { Mean } \pm 95 \% \text { C.I. }\end{array}$ & $F$ \\
\hline Tiantu (CV22) & $4.46 \pm 0.42$ & $3.69 \pm 0.46$ & $3.01 \pm 0.80$ & $7.39^{*}$ \\
\hline Xuanji (CV21) & $1.37 \pm 0.27$ & $1.03 \pm 0.25$ & $0.41 \pm 0.33$ & $9.81^{*}$ \\
\hline Huagai (CV20) & $1.18 \pm 0.29$ & $0.88 \pm 0.23$ & $0.49 \pm 0.38$ & $5.24^{*}$ \\
\hline Zigong (CV19) & $1.32 \pm 0.24$ & $0.97 \pm 0.19$ & $0.50 \pm 0.40$ & $9.73^{*}$ \\
\hline Yutang (CV18) & $1.42 \pm 0.25$ & $1.00 \pm 0.20$ & $0.56 \pm 0.46$ & $9.89^{*}$ \\
\hline Danzhong (CV17) & $1.55 \pm 0.23$ & $1.07 \pm 0.22$ & $0.71 \pm 0.57$ & $8.63^{*}$ \\
\hline Zhongting (CV16) & $1.75 \pm 0.003$ & $1.41 \pm 0.32$ & $0.90 \pm 0.76$ & $4.17^{*}$ \\
\hline Shufu (KI27) & $4.31 \pm 0.72$ & $3.36 \pm 0.47$ & $2.23 \pm 0.46$ & $9.90^{*}$ \\
\hline Yuzhong (KI26) & $2.93 \pm 0.44$ & $2.46 \pm 0.33$ & $1.53 \pm 0.55$ & $9.31^{*}$ \\
\hline Shencang (KI25) & $2.69 \pm 0.39$ & $2.29 \pm 0.29$ & $1.53 \pm 0.46$ & $8.35^{*}$ \\
\hline Lingxu (KI24) & $2.70 \pm 0.35$ & $2.40 \pm 0.26$ & $1.69 \pm 0.57$ & $7.19^{*}$ \\
\hline Shenfeng (KI23) & $2.89 \pm 0.32$ & $2.46 \pm 0.24$ & $1.79 \pm 0.60$ & $9.52^{*}$ \\
\hline Bulang (KI22) & $2.95 \pm 0.30$ & $2.49 \pm 0.23$ & $1.79 \pm 0.45$ & $11.15^{*}$ \\
\hline Qihu (ST13) & $4.73 \pm 0.77$ & $3.75 \pm 0.57$ & $2.46 \pm 1.10$ & $8.14^{*}$ \\
\hline Kufang (ST14) & $3.51 \pm 0.51$ & $3.04 \pm 0.45$ & $2.06 \pm 1.07$ & $5.52^{*}$ \\
\hline Wuyi (ST15) & $3.05 \pm 0.52$ & $2.72 \pm 0.38$ & $1.76 \pm 0.82$ & $5.61^{*}$ \\
\hline Yingchuang (ST16) & $2.94 \pm 0.47$ & $2.66 \pm 0.37$ & $1.90 \pm 0.78$ & $4.08^{*}$ \\
\hline Ruzhong (ST17) & $2.91 \pm 0.42$ & $2.58 \pm 0.33$ & $1.93 \pm 0.62$ & $4.73^{*}$ \\
\hline Rugen (ST18) & $2.9200 \pm 0.4038$ & $2.444 \pm 0.3052$ & $1.6857 \pm 0.5636$ & $9.4451^{*}$ \\
\hline Tianchi (PC1) & $3.34 \pm 0.69$ & $2.86 \pm 0.37$ & $1.89 \pm 0.73$ & $5.37^{*}$ \\
\hline Yunmen (LU1) & $5.84 \pm 0.79$ & $4.42 \pm 0.76$ & $3.51 \pm 1.59$ & $6.52^{*}$ \\
\hline Zhongfu (LU2) & $4.43 \pm 0.55$ & $3.74 \pm 0.47$ & $2.81 \pm 1.45$ & $5.39^{*}$ \\
\hline Zhourong (SP20) & $3.82 \pm 0.59$ & $3.49 \pm 0.46$ & $2.37 \pm 1.15$ & $4.72^{*}$ \\
\hline Xiongxiang (SP19) & $3.70 \pm 0.53$ & $3.31 \pm 0.42$ & $2.23 \pm 0.82$ & $6.40^{*}$ \\
\hline Tianxi (SP18) & $3.41 \pm 0.53$ & $3.06 \pm 0.44$ & $2.07 \pm 0.79$ & $5.25^{*}$ \\
\hline Shidou (SP17) & $3.34 \pm 0.53$ & $2.80 \pm 0.40$ & $1.83 \pm 0.72$ & $7.49^{*}$ \\
\hline Zhejin (GB23) & $3.63 \pm 0.57$ & $3.43 \pm 0.43$ & $2.24 \pm 0.99$ & $5.24^{*}$ \\
\hline Yuanye (GB22) & $4.06 \pm 0.64$ & $3.72 \pm 0.54$ & $2.39 \pm 1.08$ & $5.48^{*}$ \\
\hline
\end{tabular}

$X$ : mean depth; units are provided in centimeters.

$X \pm 1.96$ SD: $95 \%$ confidence interval.

${ }^{*} P<0.01 ; F$ is the statistic for one-way ANOVA.

The definitions for "Overweight adults," "Normal adults," and "Underweight adults" are following the guidance of the Department of Health, Taiwan: "The suggested ideal body weight of Taiwanese people." As such, readers from outside Taiwan should bear in mind that ideal body weights differ between countries. The specified needling depths in the table are a suggested guide only.

is the most widely used method to show the increase in fat amount in the whole body. Nevertheless, BMI does not reliably reflect the body fat composition as only body weight and length are taken into consideration [121]. Fat distribution and sexual dimorphism further explain the likely existing gender difference $[122,123]$. Mathematician Nick Trefethen believes that the body mass index formula traditionally used to work out if someone is overweight is flawed, and he has come up with his own formula. And he found short people are actually more overweight than they think they are, while tall people are not as overweight as they are being told (Daily Mail. PUBLISHED: 00:08 GMT, January 21, 2013). He claimed a new method for calculating BMI, but again only body height and weight are considered as reference factors. Probably along with waist and neck girth, simple anthropometric measures could amend the weakness of BMI as a single indicator of body size.
We hereby recommend future research suggestions regarding determining the safe needling depth. Firstly, an international congress should be convened to reach unanimous agreement on the definition of safe needling depth of each acupuncture point and acupuncture point localization method for the future study design. Secondly, factors like gender, age, BMI (or other index to differentiate body sizes), right/left side of the limb, insertion angle, and de-qi should be controlled as much as possible. Subjects (maybe crossing races) should be as many as possible, and the study design should better be randomized control studies. We should try our best to cover every acupuncture point in the whole body. Thirdly, in vivo research is better than retrospective images or specimen dissections. MRI seems to be a better tool to obtain more detailed information of anatomical structures surrounding the acupuncture needle, especially the soft tissue. Fourthly, we also suggest that multicenter 
TABLE 9: Mean values for needling depths of acupoints in the back from different-sized male subjects.

\begin{tabular}{|c|c|c|c|c|}
\hline Acupoints & $\begin{array}{l}\text { Overweight adults } \\
\text { Mean } \pm 95 \% \text { C.I. }\end{array}$ & $\begin{array}{c}\text { Normal adults } \\
\text { Mean } \pm 95 \% \text { C.I. }\end{array}$ & $\begin{array}{c}\text { Underweight adults } \\
\text { Mean } \pm 95 \% \text { C.I. }\end{array}$ & $F$ \\
\hline Dazhui (GV14) & $6.76 \pm 0.41$ & $5.39 \pm 0.40$ & $4.81 \pm 0.54$ & $20.90^{*}$ \\
\hline Taodao (GV13) & $6.35 \pm 0.40$ & $5.24 \pm 0.40$ & $4.66 \pm 0.47$ & $17.03^{*}$ \\
\hline Shenzhu (GV12) & $5.39 \pm 0.37$ & $4.79 \pm 0.35$ & $4.10 \pm 0.34$ & $14.13^{*}$ \\
\hline Shendao (GV11) & $4.86 \pm 0.32$ & $4.30 \pm 0.30$ & $3.65 \pm 0.23$ & $18.95^{*}$ \\
\hline Lingtai (GV10) & $4.88 \pm 0.32$ & $4.27 \pm 0.30$ & $3.56 \pm 0.21$ & $22.69^{*}$ \\
\hline Zhiyang (GV9) & $4.86 \pm 0.33$ & $4.20 \pm 0.27$ & $3.47 \pm 0.19$ & $27.32^{*}$ \\
\hline Jianzhongshu (SI15) & $7.43 \pm 0.50$ & $6.47 \pm 0.59$ & $5.77 \pm 0.70$ & $8.18^{*}$ \\
\hline Dazhu (BL11) & $6.98 \pm 0.54$ & $6.19 \pm 0.49$ & $5.36 \pm 0.79$ & $7.33^{*}$ \\
\hline Fengmen (BL12) & $6.21 \pm 0.50$ & $5.53 \pm 0.47$ & $5.08 \pm 0.77$ & $3.95^{*}$ \\
\hline Feishu (BL13) & $5.70 \pm 0.49$ & $5.15 \pm 0.48$ & $4.67 \pm 0.66$ & $3.73^{*}$ \\
\hline Jueyinshu (BL14) & $5.37 \pm 0.47$ & $4.76 \pm 0.41$ & $4.39 \pm 0.57$ & $4.42^{*}$ \\
\hline Xinshu (BL15) & $5.04 \pm 0.67$ & $4.54 \pm 0.43$ & $4.27 \pm 0.50$ & $2.25^{*}$ \\
\hline Dushu (BL16) & $5.18 \pm 0.47$ & $4.52 \pm 0.48$ & $4.13 \pm 0.45$ & $5.34^{*}$ \\
\hline Geshu (BL17) & $5.30 \pm 0.47$ & $4.55 \pm 0.46$ & $4.18 \pm 0.47$ & $6.28^{*}$ \\
\hline Jianwaishu (SI14) & $6.05 \pm 0.39$ & $5.39 \pm 0.43$ & $5.00 \pm 0.63$ & $4.79^{*}$ \\
\hline Fufen (BL41) & $5.10 \pm 0.45$ & $4.37 \pm 0.37$ & $4.38 \pm 0.59$ & $3.40^{*}$ \\
\hline Pohu (BL42) & $4.40 \pm 0.37$ & $3.75 \pm 0.35$ & $3.56 \pm 0.50$ & $5.06^{*}$ \\
\hline Gaohuang (BL43) & $3.98 \pm 0.35$ & $3.34 \pm 0.35$ & $2.98 \pm 0.41$ & $7.99^{*}$ \\
\hline Shentang (BL44) & $3.75 \pm 0.36$ & $2.98 \pm 0.30$ & $2.57 \pm 0.35$ & $13.39^{*}$ \\
\hline Yixi (BL45) & $3.70 \pm 0.46$ & $2.76 \pm 0.28$ & $2.28 \pm 0.37$ & $16.03^{*}$ \\
\hline Geguan (BL46) & $3.66 \pm 0.45$ & $2.63 \pm 0.28$ & $2.33 \pm 0.36$ & $15.08^{*}$ \\
\hline Quyuan (SI13) & $5.36 \pm 0.32$ & $4.76 \pm 0.35$ & $4.31 \pm 0.42$ & $8.78^{*}$ \\
\hline
\end{tabular}

$X$ : mean depth; units are provided in centimeters.

$X \pm 1.96$ SD: $95 \%$ confidence interval.

${ }^{*} P<0.01 ; F$ is the statistic for one-way ANOVA.

The definitions for "Overweight adults," "Normal adults," and "Underweight adults" are following the guidance of the Department of Health, Taiwan: "The suggested ideal body weight of Taiwanese people." As such, readers from outside Taiwan should bear in mind that ideal body weights differ between countries. The specified needling depths in the table are a suggested guide only.

should collaboration be carried out to collect statistically valuable information that can be used to increase the safety of acupuncture. Difference among different measuring methods can be understood better.

When it comes to the discussion of clinical effect of acupuncture, de-qi is frequently mentioned. De-qi means a sensation that is often elicited to enhance the effect of acupuncture treatment $[124,125]$. In the ancient acupuncture literature (Huangdi) Neijing chapter Suwen indicated that de-qi may have the root in subcutaneous tissue, connective tissues, and muscles layers according to variable conditions including severity of diseases. Some practitioners of acupuncture refer to de-qi as "needle grasp," a biomechanical phenomenon characterized by an increase in the force necessary to pull the needle out of the tissue. It has been proposed that the sensation of needle grasp is due to the contraction of skeletal muscle [126] or winding of connective tissue around the needle during needle rotation [127]. By using electric impedance, Lin showed that muscle layers were the major site of de-qi in the 22 acupoints in the back [128]. The role of the nervous system in de-qi has also been well described, and some researches in this review shared their opinions as well $[24,129]$. The relevant nerves can be found in certain region surrounding the acupuncture point, and it is likely that nerves are provoked during needle manipulation. As discrepancy in definition, mechanism, and location of de-qi still exists, the depth to elicit de-qi in each point and the correlation with clinical efficacy warrants, further researches.

Only limited researches addressed the needling depth with therapeutic efficacy with good designs, and were not all acupuncture points were investigated thoroughly. Lin conducted a meta-analysis of the published evidence concerning acupoint needling depths, with the aim of providing a uniform guidance. Their group's CT scanning results indicate safe needling depths for acupoints in the back and chest for different-sized people, that is, normal, over- and underweight adults, and for sex differences (Tables 7, 8, 9, and 10) [130].

Some clinicians have shared their clinical experiences about the optimal needling depth of to treat some diseases [131]. As there are still a lot of confusions in needling depth of acupuncture points from the ancient times to the present, which has negatively influenced the standardization and international exchanges of acupuncture science, it remains to be settled as soon as possibly [132]. After convinced that acupuncture is inherently safe, how to avoid the possible associated adverse events and complications is a top priority. 
TABLE 10: Mean values for needling depths of acupoints in the back in different-sized female subjects.

\begin{tabular}{|c|c|c|c|c|}
\hline Acupoints & $\begin{array}{l}\text { Overweight adults } \\
\text { Mean } \pm 95 \% \text { C.I. }\end{array}$ & $\begin{array}{c}\text { Normal adults } \\
\text { Mean } \pm 95 \% \text { C.I. }\end{array}$ & $\begin{array}{c}\text { Underweight adults } \\
\text { Mean } \pm 95 \% \text { C.I. }\end{array}$ & $F$ \\
\hline Dazhui (GV14) & $6.37 \pm 0.71$ & $5.21 \pm 0.70$ & $4.35 \pm 0.19$ & $5.91^{*}$ \\
\hline Taodao (GV13) & $6.01 \pm 0.45$ & $4.97 \pm 0.58$ & $4.13 \pm 0.88$ & $8.58^{*}$ \\
\hline Shenzhu (GV12) & $5.36 \pm 0.35$ & $4.40 \pm 0.39$ & $3.60 \pm 0.64$ & $15.31^{*}$ \\
\hline Shendao (GV11) & $5.01 \pm 0.38$ & $3.97 \pm 0.30$ & $3.40 \pm 0.64$ & $18.12^{*}$ \\
\hline Lingtai (GV10) & $4.89 \pm 0.35$ & $3.83 \pm 0.28$ & $3.28 \pm 0.63$ & $21.03^{*}$ \\
\hline Zhiyang (GV9) & $4.90 \pm 0.41$ & $3.86 \pm 0.29$ & $3.37 \pm 0.67$ & $15.06^{*}$ \\
\hline Jianzhongshu (SI15) & $6.62 \pm 0.48$ & $5.87 \pm 0.62$ & $4.15 \pm 1.36$ & $10.43^{*}$ \\
\hline Dazhu (BL11) & $6.42 \pm 0.53$ & $5.39 \pm 0.62$ & $4.27 \pm 0.96$ & $8.77^{*}$ \\
\hline Fengmen (BL12) & $5.83 \pm 0.39$ & $4.78 \pm 0.61$ & $4.13 \pm 1.08$ & $6.97^{*}$ \\
\hline Feishu (BL13) & $5.32 \pm 0.38$ & $4.43 \pm 0.46$ & $4.03 \pm 0.97$ & $6.66^{*}$ \\
\hline Jueyinshu (BL14) & $5.07 \pm 0.47$ & $4.25 \pm 0.43$ & $3.73 \pm 0.87$ & $6.40^{*}$ \\
\hline Xinshu (BL15) & $4.91 \pm 0.51$ & $3.97 \pm 0.32$ & $3.63 \pm 0.88$ & $8.36^{*}$ \\
\hline Dushu (BL16) & $4.90 \pm 0.49$ & $3.86 \pm 0.30$ & $3.63 \pm 0.80$ & $10.35^{*}$ \\
\hline Geshu (BL17) & $4.91 \pm 0.47$ & $3.92 \pm 0.37$ & $3.58 \pm 0.92$ & $8.57^{*}$ \\
\hline Jianwaishu (SI14) & $5.57 \pm 0.41$ & $4.91 \pm 0.48$ & $3.85 \pm 0.81$ & $8.83^{*}$ \\
\hline Fufen (BL41) & $4.85 \pm 0.31$ & $4.07 \pm 0.42$ & $3.07 \pm 0.85$ & $12.60^{*}$ \\
\hline Pohu (BL42) & $4.35 \pm 0.28$ & $3.53 \pm 0.31$ & $2.60 \pm 0.74$ & $19.67^{*}$ \\
\hline Gaohuang (BL43) & $3.96 \pm 0.32$ & $3.15 \pm 0.31$ & $2.30 \pm 0.61$ & $18.00^{*}$ \\
\hline Shentang (BL44) & $3.67 \pm 0.35$ & $2.75 \pm 0.27$ & $2.02 \pm 0.48$ & $21.33^{*}$ \\
\hline Yixi (BL45) & $3.59 \pm 0.37$ & $2.56 \pm 0.23$ & $1.88 \pm 0.54$ & $24.99^{*}$ \\
\hline Geguan (BL46) & $3.59 \pm 0.40$ & $2.53 \pm 0.28$ & $1.78 \pm 0.49$ & $22.77^{*}$ \\
\hline Quyuan (SI13) & $5.16 \pm 0.37$ & $4.32 \pm 0.39$ & $3.08 \pm 0.58$ & $18.83^{*}$ \\
\hline
\end{tabular}

$X$ : mean depth; units are provided in centimeters.

$X \pm 1.96$ SD: $95 \%$ confidence interval.

${ }^{*} P<0.01 ; F$ is the statistic for one-way ANOVA.

The definitions for "Overweight adults," "Normal adults," and "Underweight adults" are following the guidance of the Department of Health, Taiwan: "The suggested ideal body weight of Taiwanese people." As such, readers from outside Taiwan should bear in mind that ideal body weights differ between countries. The specified needling depths in the table are a suggested guide only.

We should put more efforts on how to reduce the risk by starting exploring the safe needling depth as well as the depth of clinical efficacy efficiently and correctly.

\section{Conclusion}

From the current review we found that there is great inconsistency in terms of safe needling depths measured from different subject groups and via different measuring tools. The depths measured in each research were somehow influenced by the different measuring methods as they all have distinguished advantages/disadvantages as compared with one another. The results of related researches fail to provide the solid support to decide the best measuring tool among conventional cadaver specimens, CT, MRI or ultrasound either. The characteristics of subjects such as ethnicity, gender, age, body size, underlying diseases, and the needling details (such as needling angle, which anatomical region of the body, which side of the body, and if with de-qi) all contributed partially to the measured depths. The definition of safe depth and standard localization method should be established by standardization through international conference. There is also lack of well-designed researches to compare the therapeutic effects thus making the proper needling depth of clinical efficacy in each acupuncture point remain obscure. A well-designed clinical trial (to control variable strictly, recruit more subjects, etc.) to decide the actual and advisable needling depth for each acupuncture point, to avoid adverse effects or complications and promote optimal clinical efficacy, is a top priority. In vivo MRI imaging may serve as a good study method.

Different levels of treatment assessment of acupuncture then can be suggested by European Information Centre on complementary and Alternative Medicine (EICCAM II), that is, efficacy (is it more effective than placebo or standard?), effectiveness (is it helpful in usual care?) and efficiency (how is the cost benefit relation?).

\section{Conflict of Interests}

The authors have indicated no financial conflict of interests.

\section{Authors' Contribution}

Jaung-Geng Lin and Pei-Chi Chou contributed equally to this work, and Jaung-Geng Lin, Pei-Chi Chou and Heng-Yi Chu should be considered co-first authors. 


\section{Acknowledgments}

This paper is sponsored by the Project: CMU100-N2-02 from China Medical University, Taichung, Taiwan, and NSC 1012320-B-039-035-MY3 from the National Science Council, Taipei, Taiwan.

\section{References}

[1] P. M. Barnes, B. Bloom, and R. L. Nahin, "Complementary and alternative medicine use among adults and children: United States, 2007," National Health Statistics Reports, vol. 10, no. 12, pp. 1-23, 2008.

[2] H. MacPherson and R. Hammerschlag, "Acupuncture and the emerging evidence base: contrived controversy and rational debate," Journal of Acupuncture and Meridian Studies, vol. 5, no. 4, pp. 141-147, 2012.

[3] D. Melchart, W. Weidenhammer, A. Streng et al., "Prospective investigation of adverse effects of acupuncture in 97733 patients," Archives of Internal Medicine, vol. 164, no. 1, pp. 104105, 2004.

[4] P. Posadzki, A. Alotaibi, and E. Ernst, "Prevalence of use of complementary and alternative medicine (CAM) by physicians in the UK: a systematic review of surveys," Clinical Medicine, vol. 12, no. 6, pp. 505-512, 2012.

[5] P. Fisher and A. Ward, "Complementary medicine in Europe," British Medical Journal, vol. 309, no. 6947, pp. 107-111, 1994.

[6] K. Thomas and P. Coleman, "Use of complementary or alternative medicine in a general population in Great Britain. Results from the National Omnibus survey," Journal of Public Health, vol. 26, no. 2, pp. 152-157, 2004.

[7] S. Lim, "WHO standard acupuncture point locations," Evidence-Based Complementary and Alternative Medicine, vol. 7, no. 2, pp. 167-168, 2010.

[8] G. Li, A study on acupuncture security of Ganshu [M.S. thesis], Department of Clinical Medicine, Heilongjiang University of Chinese Medicine, Beijing, China, 2011.

[9] Y. Fu, Study of acupuncture safety of Pishu [M.S. thesis], Department of Clinical Medicine, Heilongjiang University of Chinese Medicine, Beijing, China, 2011.

[10] S. Chuan, Acupuncture point of Danshu: acupuncture security research [M.S. thesis], Clinical Medical Science, Heilongjiang University of Chinese Medicine, Beijing, China, 2011.

[11] Y. J. Yen, The safety research of acupuncture Geshu [M.S. thesis], Department of Clinical Medicine, Heilongjiang University of Chinese Medicine, Beijing, China, 2011.

[12] Q. C. Han, The security of acupuncturing Dabao acupoint [M.S. thesis], Department of Clinical Medicine, Heilongjiang University of Chinese Medicine, Beijing, China, 2010.

[13] Y. Wen, X. L. Li, D. N. Cao, Q. C. Han, F. Wang, and W. P. Cheng, "On needling depth of Dabao acupoint with MRI," Journal of Clinical Acupuncture and Moxibustion, vol. 27, no. 7, pp. 7-8, 2011.

[14] F. Yu, The study of acupuncture security of Juque and Burong [M.S. thesis], Department of Clinical Medicine, Heilongjiang University of Chinese Medicine, Beijing, China, 2010.

[15] G. Ho, Research of the security by acupuncture Rugen and Riyue [M.S. thesis], Department of Clinical Medicine, Heilongjiang University of Chinese Medicine, Beijing, China, 2010.

[16] D. Wu, The study on acupuncture security of Qimen (LR14) [M.S. thesis], Department of Clinical Medicine, Heilongjiang University of Chinese Medicine, Beijing, China, 2010.
[17] S. P. Dong, The study of acupuncture security of Jiuwei and Shangwan [M.S. thesis], Department of Clinical Medicine, Heilongjiang University of Chinese Medicine, Beijing, China, 2010.

[18] W. P. Cheng and S. P. Dong, "Discussion on the safe angle and depth of acupuncture at Jiuwei (CV 15)," Zhongguo Zhen Jiu, vol. 32, no. 6, pp. 515-518, 2012.

[19] C. Wang, The study on acupuncture security of Tianzhu (BL10) [M.S. thesis], Clinical Medical Science, Heilongjiang University of Chinese Medicine, Beijing, China, 2009.

[20] H. Chang, The study of acupuncture safety of Fengchi [M.S. thesis], Department of Clinical Medicine, Heilongjiang University of Chinese Medicine, Beijing, China, 2009.

[21] H. Bai, Study on acupuncture security of Fenfu(DU16) [M.S. thesis], Department of Clinical Medicine, Heilongjiang University of Chinese Medicine, Beijing, China, 2009.

[22] Y. Wu, Study of acupuncture safety of Jingming (Bl1) and Chengqi (ST1) [M.S. thesis], Department of Clinical Medicine, Heilongjiang University of Chinese Medicine, Beijing, China, 2009.

[23] Y. Y. Lu, The study of acupuncture security of Yamen (Du15) [M.S. thesis], Department of Clinical Medicine, Heilongjiang University of Chinese Medicine, Beijing, China, 2009.

[24] D. H. W. Groenemeyer, L. Zhang, S. Schirp, and J. Baier, "Localization of acupuncture points BL25 and BL26 using computed tomography," Journal of Alternative and Complementary Medicine, vol. 15, no. 12, pp. 1285-1291, 2009.

[25] K. Streitberger, U. Eichenberger, A. Schneider, S. Witte, and M. Greher, "Ultrasound measurements of the distance between acupuncture needle tip at P6 and the median nerve," Journal of Alternative and Complementary Medicine, vol. 13, no. 5, pp. 585591, 2007.

[26] G. R. Dong, Y.-D. Li, Q. Xu et al., "Applying the CT measures the urine bladder through the second side line seven caves enter the research of the needle depth," Journal of Clinical Acupuncture and Moxibustion, vol. 20, no. 11, p. 3, 2004.

[27] Y. D. Li, J. N. Li, and H. Y. Dong, "Applying the CT measures the urine bladder through the first side line seven caves enter the directional research in depth, angle in needle," Journal of Clinical Acupuncture and Moxibustion, vol. 20, no. 10, p. 5, 2004.

[28] Q. Z. He, J. S. Hao, F. Zhang et al., "Clinical study on safe depth for needling Dazhui (GV 14)," Chinese Acupuncture \& Moxibustion, vol. 24, no. 10, pp. 723-724, 2004.

[29] J.-G. Lin, "Studies of needling depth in acupuncture treatment," Chinese Medical Journal, vol. 110, no. 2, pp. 154-156, 1997.

[30] Z. G. Lin and Q. F. Wang, "Depth of getting qi in clinical practice," Zhongguo Zhong Xi Yi Jie He Za Zhi, vol. 14, no. 2, pp. 94-95, 1994.

[31] J. G. Lin, "Evaluation of the depth of de-qi for various acupuncture loci on human thorax and correlation between de-qi and electric resistance," Chinese Journal of Integrated Traditional and Western Medicine, vol. 11, no. 10, pp. 628-630, 1991.

[32] H.-N. Chen, J.-G. Lin, L.-C. Ying, C.-C. Huang, and C.-H. Lin, "The therapeutic depth of abdominal acupuncture points approaches the safe depth in overweight and in older children," Journal of Alternative and Complementary Medicine, vol. 15, no. 9, pp. 1033-1037, 2009.

[33] S.-D. Yang, Y.-D. Li, G.-H. Jiang, N.-N. Hu, and S.-Y. Cong, "Study on needling depth of Fengfu (GV 16) with CT," Zhongguo Zhen Jiu, vol. 28, no. 1, pp. 47-48, 2008. 
[34] H.-N. Chen, J.-G. Lin, A. D. Yang, and S.-K. Chang, "Safe depth of abdominal acupoints in pediatric patients," Complementary Therapies in Medicine, vol. 16, no. 6, pp. 331-335, 2008.

[35] W. P. Chern, Y. D. Li, and F. L. Wan, "The study of safe needling depth of BL 13 by CT scan," Heilongjiang Journal of Traditional Chinese Medicine, vol. 6, article 43, 2006.

[36] Y. D. Li, S. D. Yang, J. N. Li, and L. Li, "Study on needling depth of Dazhui (GV 14), Jianzhongshu (SI 15), Xuanshu (GV 5) and Mingmen (GV 4) with CT,' Zhongguo Zhen Jiu, vol. 25, no. 12, pp. 863-864, 2005.

[37] C. Y. Sheu and J. G. Lin, "Detection of the safety depth on human chest by computer tomographic scanning," Zhonghua Yi Xue Za Zhi, vol. 50, no. 5, pp. 388-399, 1992.

[38] J. G. Lin, C. Y. She, and W. S. Huang, "Detecting the safety depth on human back loci by computer tomographic scanning," Chinese Journal of Integrated Traditional and Western Medicine, vol. 11, no. 1, pp. 10-3, 1991.

[39] A. C. Ahn, A. P. Colbert, B. J. Anderson et al., "Electrical properties of acupuncture points and meridians: a systematic review," Bioelectromagnetics, vol. 29, no. 4, pp. 245-256, 2008.

[40] H. Heine, "Anatomical structure of acupoints," Journal of Traditional Chinese Medicine, vol. 8, no. 3, pp. 207-212, 1988.

[41] H. M. Langevin and J. A. Yandow, "Relationship of acupuncture points and meridians to connective tissue planes," Anatomical Record, vol. 269, no. 6, pp. 257-265, 2002.

[42] H. M. Langevin, D. L. Churchill, J. Wu et al., "Evidence of connective tissue involvement in acupuncture," The FASEB Journal, vol. 16, no. 8, pp. 872-874, 2002.

[43] T. B. Halvorsen, S. S. Anda, A. B. Naess, and O. W. Levang, "Fatal cardiac tamponade after acupuncture through congenital sternal foramen," The Lancet, vol. 345, no. 8958, p. 1175, 1995.

[44] J. Hasegawa, N. Noguchi, J. Yamasaki et al., "Delayed cardiac tamponade and hemothorax induced by an acupuncture needle," Cardiology, vol. 78, no. 1, pp. 58-63, 1991.

[45] M. Ding, Y. Qiu, Z. Jiang, L. Tang, and C. Jin, "Acupunctureassociated pneumothorax," Journal of Alternative and Complementary Medicine, vol. 19, no. 6, pp. 564-568, 2013.

[46] W. He, X. Zhao, Y. Li, Q. Xi, and Y. Guo, "Adverse events following acupuncture: a systematic review of the Chinese literature for the years 1956-2010," Journal of Alternative and Complementary Medicine, vol. 18, no. 10, pp. 892-901, 2012.

[47] D. B. Jefferys, S. Smith, D. A. Brennand Roper, and P. V. L. Curry, "Acupuncture needles as a cause of bacterial endocarditis," British Medical Journal, vol. 287, no. 6388, pp. 326-327, 1983.

[48] O. Scheel, A. Sundsfjord, P. Lunde, and B. M. Andersen, "Endocarditis after acupuncture and injection-treatment by a natural healer," Journal of the American Medical Association, vol. 267, no. 1, p. 56, 1992.

[49] R. J. E. Lee and J. C. McIlwain, "Subacute bacterial endocarditis following ear acupuncture," International Journal of Cardiology, vol. 7, no. 1, pp. 62-63, 1985.

[50] H. Yamashita, H. Tsukayama, A. R. White, Y. Tanno, C. Sugishita, and E. Ernst, "Systematic review of adverse events following acupuncture: the Japanese literature," Complementary Therapies in Medicine, vol. 9, no. 2, pp. 98-104, 2001.

[51] P. E. Slater, P. Ben-Ishai, A. Leventhal et al., "An acupunctureassociated outbreak of hepatitis B in Jerusalem," European Journal of Epidemiology, vol. 4, no. 3, pp. 322-325, 1988.

[52] G. P. Kent, J. Brondum, R. A. Keenlyside, L. M. LaFazia, and H. D. Scott, "A large outbreak of acupuncture-associated hepatitis B," American Journal of Epidemiology, vol. 127, no. 3, pp. 591-598, 1988.
[53] M. Inayama, T. Shinohara, H. Hino, M. Yoshida, and F. Ogushi, "Chylothorax caused by acupuncture," Internal Medicine, vol. 50, no. 20, pp. 2375-2377, 2011.

[54] L. Lao, G. R. Hamilton, J. Fu, and B. M. Berman, "Is acupuncture safe? A systematic review of case reports," Alternative Therapies in Health and Medicine, vol. 9, no. 1, pp. 72-83, 2003.

[55] S. K. Verma and R. Khamesra, "Recurrent fainting - an unusual reaction to acupuncture," The Journal of the Association of Physicians of India, vol. 37, no. 9, p. 600, 1989.

[56] J. Wheway, T. B. Agbabiaka, and E. Ernst, "Patient safety incidents from acupuncture treatments: a review of reports to the National Patient Safety Agency," International Journal of Risk and Safety in Medicine, vol. 24, no. 3, pp. 163-169, 2012.

[57] A. N. Castro-Silva, A. O. Freire, R. S. Grinbaum et al., "Cutaneous Mycobacterium haemophilum infection in a kidney transplant recipient after acupuncture treatment," Transplant Infectious Disease, vol. 13, no. 1, pp. 33-37, 2011.

[58] M. Morimoto, K. Kawata, N. Tsuchiya, H. Murakami, M. Kura, and Y. Koga, "A case of acupuncture needle dermatitis," Masui, vol. 49, no. 8, pp. 887-889, 2000.

[59] H. Koizumi, T. Tomoyori, M. Kumakiri, and A. Ohkawara, "Acupuncture needle dermatitis," Contact Dermatitis, vol. 21, no. 5, p. 352, 1989.

[60] A. A. Fisher, "Allergic dermatitis from acupuncture needles," Cutis, vol. 38, no. 4, p. 226, 1986.

[61] A. J. Norheim, "Adverse effects of acupuncture: a study of the literature for the years 1981-1994," Journal of Alternative and Complementary Medicine, vol. 2, no. 2, pp. 291-297, 1996.

[62] P. Rosted, "Risks and adverse effects of acupuncture therapy," Ugeskrift for Laeger, vol. 156, no. 49, pp. 7335-7339, 1994.

[63] A. J. Norheim, "Complications of acupuncture therapy. A study of the literature from 1981-92," Tidsskrift for den Norske Laegeforening, vol. 114, no. 10, pp. 1192-1194, 1994.

[64] H. Yamashita and H. Tsukayama, "Safety of acupuncture practice in Japan: patient reactions, therapist negligence and error reduction strategies," Evidence-Based Complementary and Alternative Medicine, vol. 5, no. 4, pp. 391-398, 2008.

[65] D. A. Mazal, T. King, J. Harvey, and J. Cohen, "Bilateral pneumothorax after acupuncture," The New England Journal of Medicine, vol. 302, no. 24, pp. 1365-1366, 1980.

[66] L. J. Valenta and J. W. Hengesh, "Pneumothorax caused by acupuncture," The Lancet, vol. 2, no. 8189, p. 322, 1980.

[67] R. S. Wright, J. L. Kupperman, and M. I. Liebhaber, "Bilateral tension pneumothoraces after acupuncture," Western Journal of Medicine, vol. 154, no. 1, pp. 102-103, 1991.

[68] R. Gray, G. S. Maharajh, and R. Hyland, "Pneumothorax resulting from acupuncture," Canadian Association of Radiologists Journal, vol. 42, no. 2, pp. 139-140, 1991.

[69] R. D. M. de Kuyper and E. J.van Hezik, "Bilateral pneumothorax in a young woman following acupuncture," Nederlands Tijdschrift voor Geneeskunde, vol. 146, no. 24, p. 1158, 2002.

[70] D. Ramnarain and R. Braams, "Bilateral pneumothorax in a young woman following acupuncture," Nederlands Tijdschrift voor Geneeskunde, vol. 146, no. 4, pp. 172-175, 2002.

[71] R. Cantan, N. Milesi-Defrance, K. Hardenberg, M. Vernet, I. Messant, and M. Freysz, "Bilateral pneumothorax and tamponade after acupuncture," Presse Medicale, vol. 32, no. 7, pp. 311-312, 2003.

[72] N. Morrone, J. A. Freire, A. K. Ferreira, and A. M. Dourado, "Iatrogenic pneumothorax caused by acupuncture," Revista Paulista de Medicina, vol. 108, no. 4, pp. 189-191, 1990. 
[73] R. M. Terra, A. Fernandez, R. H. Bammann, A. C. P. Castro, A. Ishy, and J. J. M. Junqueira, "Pneumothorax after acupuncture: clinical presentation and management," Revista da Associacao Medica Brasileira, vol. 53, no. 6, pp. 535-538, 2007.

[74] S. A. Andersen, "Bilateral pneumothorax efter akupunktur," Ugeskrift for Laeger, vol. 173, no. 43, pp. 2724-2725, 2011.

[75] C.-L. Kao and J.-P. Chang, "Bilateral pneumothorax after acupuncture," Journal of Emergency Medicine, vol. 22, no. 1, pp. 101-102, 2002.

[76] K. Iwadate, H. Ito, S. Katsumura et al., "An autopsy case of bilateral tension pneumothorax after acupuncture," Legal Medicine, vol. 5, no. 3, pp. 170-174, 2003.

[77] D.-Y. Zhao and G.-L. Zhang, "Clinical analysis on 38 cases of pneumothorax induced by acupuncture or acupoint injection," Zhongguo Zhen Jiu, vol. 29, no. 3, pp. 239-242, 2009.

[78] W. M. Lee, H. B. Leung, and W. C. Wong, "Iatrogenic bilateral pneumothorax arising from acupuncture: a case report," Journal of Orthopaedic Surgery, vol. 13, no. 3, pp. 300-302, 2005.

[79] W. J. Lian, "Using ultrasound to detect acupoints BL11 to BL21," Zhen Jiu Lin Chuang Za Zhi, vol. 11, article 1, 1995.

[80] H. J. Oh, Y. K. Ko, S. S. Cho, and S. P. Yoon, "A cadaveric study of needle insertion at PC6 in eight wrists of four subjects and an understanding of the anatomy," Acupuncture in Medicine, vol. 30, no. 1, pp. 44-46, 2012.

[81] Z.-F. Wang, Y. Chen, M.-F. Zheng et al., "Study on needling depth and direction from different acupoints to sphenopalatine ganglion," Zhongguo Zhen Jiu, vol. 29, no. 4, pp. 289-292, 2009.

[82] Y. C. Xie, Y. Chen, B. H. Wu, W. G. Zhang, and J. D. Zhang, "Safe depth for needling "Jianzhongshu" and "Dazhu" point," Journal of Fujian Medical University, vol. 41, no. 1, 2007.

[83] Y. Chen, B.-H. Wu, Y.-C. Xie et al., "Clinical anatomy study on the acupuncture safety of tiantu (CV 22) and qishe (ST 11)," Zhongguo Zhen Jiu, vol. 27, no. 2, pp. 120-122, 2007.

[84] Y. C. Xie, Y. Chen, and B. H. Wu, "Applied anatomy study on safe depth for needling Quepen point," Journal of Fujian College of Traditional Chinese Medicine, vol. 16, no. 1, pp. 24-25, 2006.

[85] Y. C. Xie, Y. Chen, and B. H. Wu, "Applied anatomy study on safe depth and angle for needling points Fengmen B12 and Feishu(B13)," Journal of Fujian College of Traditional Chinese Medicine, vol. 16, no. 5, 2006.

[86] X.-D. Xu, L.-Z. Jin, X.-F. Lou, S.-H. Sun, and S.-H. Jiang, "Anatomical study on Jingming (BL 1)," Zhongguo Zhen Jiu, vol. 26, no. 6, pp. 415-416, 2006.

[87] X.-F. Lou, X.-D. Yang, S.-H. Jiang, C.-Y. Sun, and R.-F. Zhang, "Study on angle and depth of needle insertion in acupuncture at Zusanli (ST 36)," Zhongguo Zhen Jiu, vol. 26, no. 7, pp. 483-486, 2006.

[88] Y. Chen, B.-H. Wu, Y.-C. Xie et al., "Clinically anatomic study on the relation between the form of pleural cupula and its surrounding commonly-used acupoints," Zhongguo Zhen Jiu, vol. 26, no. 5, pp. 346-348, 2006.

[89] Z. G. Yan, J. Bai, and S. L. Shao, "Study on needling depth and direction for dangerous acupoints," Chinese Acupuncture \& Moxibustion, vol. 24, no. 11, p. 4, 2004.

[90] J. H. Zhang, Z. G. Yan, and A. S. Yu, "Study on safe depth of acupuncture at commonly-used acupoints on abdomen," Chinese Acuponcture \& Moxibustion, vol. 21, no. 2, pp. 83-84, 2001.

[91] J. H. Zhang, A. S. Yu, and Y. X. Zhao, "Anatomic structure and needling depth of Quepen point (ST 12)," Chinese Acuponcture \& Moxibustion, vol. 21, no. 8, pp. 493-494, 2001.
[92] S. S. Piao and L. Q. Zhong, "The anatomical relationship between Jiajixue with lumbar vertebral posterior joint," China Journal of Orthopaedics and Traumatology, vol.14, no. 9, pp. 537$538,2001$.

[93] H. B. Chen, Y. D. Li, and L. J. Shi, "Anatomical structure of BL40," Journal of Clinical Acupuncture and Moxibustion, vol. 14, no. 4,1998 .

[94] G. F. Ge, "The correlation between thumb Tong-Shen Cun and the safe needling depth of GV15 and GV16," Journal of Zhejiang College of Traditional Chinese Medicine, vol. 22, no. 3, 1998.

[95] J. H. Zhang, Y. Zhenguo, and G. Hongchuan, "The study on the safe needling depth in the dangerous acupoints of the back," Chinese Acupuncture \& Moxibustion, vol. 7, pp. 403-404, 1998.

[96] J. H. Zhang, Z. G. Yan, and H. C. Gu, "The study on the safe needling depth in the dangerous acupoints of the chest," Shanghai Journal of Acupuncture \& Moxibustion, vol. 17, no. 6, p. 2, 1998.

[97] Z. G. Yan, J. H. Zhang, and H. C. Gu, "The study on the safe needling depth in the dangerous acupoints of head and neck," Shanghai Journal of Acupuncture \& Moxibustion, vol. 3, pp. 3738, 1996.

[98] L. He, W.-Y. Zhou, and X.-M. Zhang, "Trigeminal neuralgia of hyperactive of liver yang type treated with acupuncture at Xiaguan (ST 7) at different depth: a randomized controlled trial," Zhongguo Zhen Jiu, vol. 32, no. 2, pp. 107-110, 2012.

[99] J. J. Park, M. Akazawa, J. Ahn et al., "Acupuncture sensation during ultrasound guided acupuncture needling," Acupuncture in Medicine, vol. 29, no. 4, pp. 257-265, 2011.

[100] H. Skjeie, T. Skonnord, A. Fetveit, and M. Brekke, "A pilot study of ST36 acupuncture for infantile colic," Acupuncture in Medicine, vol. 29, no. 2, pp. 103-107, 2011.

[101] Y.-H. Lu and X.-D. Tang, "Efficacy observation on the needling depth recorded in Lingshu (Miraculous Pivot) for irritable bowel syndrome of diarrhea," Zhongguo Zhen Jiu, vol. 31, no. 11, pp. 975-977, 2011.

[102] K. Itoh, Y. Minakawa, and H. Kitakoji, "Effect of acupuncture depth on muscle pain," Chinese Medicine, vol. 6, article 24, 2011.

[103] G.-Q. Fan, Y. Zhao, and Z.-H. Fu, "Acupuncture analgesia and the direction, angle and depth of needle insertion," Zhongguo Zhen Jiu, vol. 30, no. 11, pp. 965-968, 2010.

[104] B. Fiirgaard, C. B. Pedersen, and E. Lundorf, "The size of acoustic neuromas: CT and MRI," Neuroradiology, vol. 39, no. 8, pp. 599-601, 1997.

[105] W. G. Bradley Jr., V. Waluch, R. A. Yadley, and R. R. Wycoff, "Comparison of CT and MR in 400 patients with suspected disease of the brain and cervical spinal cord," Radiology, vol. 152, no. 3, pp. 695-702, 1984.

[106] T. A. Walde, D. E. Weiland, S. B. Leung et al., "Comparison of CT, MRI, and radiographs in assessing pelvic osteolysis: a cadaveric study," Clinical Orthopaedics and Related Research, no. 437, pp. 138-144, 2005.

[107] A. H. Leitzes, H. G. Potter, T. Amaral, R. G. Marx, S. Lyman, and R. F. Widmann, "Reliability and accuracy of MRI scanogram in the evaluation of limb length discrepancy," Journal of Pediatric Orthopaedics, vol. 25, no. 6, pp. 747-749, 2005.

[108] D. Y. Yoon, J. H. Moon, H. K. Kim et al., "Comparison of lowdose CT and MR for measurement of intra-abdominal adipose tissue: a phantom and human study," Academic Radiology, vol. 15, no. 1, pp. 62-70, 2008.

[109] A.-C. Dupont, E. E. Sauerbrei, P. V. Fenton, P. C. Shragge, G. E. Loeb, and F. J. R. Richmond, "Real-time sonography to estimate 
muscle thickness: comparison with MRI and CT,' Journal of Clinical Ultrasound, vol. 29, no. 4, pp. 230-236, 2001.

[110] N. Abate, D. Burns, R. M. Peshock, A. Garg, and S. M. Grundy, "Estimation of adipose tissue mass by magnetic resonance imaging: validation against dissection in human cadavers," Journal of Lipid Research, vol. 35, no. 8, pp. 1490-1496, 1994.

[111] S. Gyftopoulos, S. Hasan, J. Bencardino et al., "Diagnostic accuracy of MRI in the measurement of glenoid bone loss," American Journal of Roentgenology, vol. 199, no. 4, pp. 873-878, 2012.

[112] M. Hirooka, T. Kumagi, K. Kurose et al., "A technique for the measurement of visceral fat by ultrasonography: comparison of measurements by ultrasonography and computed tomography," Internal Medicine, vol. 44, no. 8, pp. 794-799, 2005.

[113] B. J. Klopfenstein, M. S. Kim, C. M. Krisky, J. Szumowski, W. D. Rooney, and J. Q. Purnell, "Comparison of 3 T MRI and CT for the measurement of visceral and subcutaneous adipose tissue in humans," British Journal of Radiology, vol. 85, no. 1018, pp. e826-e830, 2012.

[114] F. Lumachi, A. Tregnaghi, P. Zucchetta et al., "Sensitivity and positive predictive value of CT, MRI and 123I-MIBG scintigraphy in localizing pheochromocytomas: a prospective study," Nuclear Medicine Communications, vol. 27, no. 7, pp. 583-587, 2006.

[115] N. Mitsiopoulos, R. N. Baumgartner, S. B. Heymsfield, W. Lyons, D. Gallagher, and R. Ross, "Cadaver validation of skeletal muscle measurement by magnetic resonance imaging and computerized tomography," Journal of Applied Physiology, vol. 85, no. 1, pp. 115-122, 1998.

[116] R. P. Stolk, O. Wink, P. M. J. Zelissen, R. Meijer, A. P. G. van Gils, and D. E. Grobbee, "Validity and reproducibility of ultrasonography for the measurement of intra-abdominal adipose tissue," International Journal of Obesity, vol. 25, no. 9, pp. 1346-1351, 2001.

[117] A. Wyler, V. Bousson, C. Bergot et al., "Comparison of MR-arthrography and CT-arthrography in hyaline cartilagethickness measurement in radiographically normal cadaver hips with anatomy as gold standard," Osteoarthritis and Cartilage, vol. 17, no. 1, pp. 19-25, 2009.

[118] C. Stevens-Simon, P. Thureen, E. Stamm, and A. Scherzinger, "A comparison of four techniques for measuring central adiposity in postpartum adolescents," Journal of Maternal-Fetal Medicine, vol. 10, no. 3, pp. 209-213, 2001.

[119] I. B. Botser, G. C. Ozoude, D. E. Martin, A. J. Siddiqi, S. Kuppuswami, and B. G. Domb, "Femoral anteversion in the hip: comparison of measurement by computed tomography, magnetic resonance imaging, and physical examination," Arthroscopy, vol. 28, no. 5, pp. 619-627, 2012.

[120] P.-C. Chou, H.-Y. Chu, and J.-G. Lin, "Safe needling depth of acupuncture points," Journal of Alternative and Complementary Medicine, vol. 17, no. 3, pp. 199-206, 2011.

[121] B. Alicioglu, A. Sarac, and B. Tokuc, "Does abdominal obesity cause increase in the amount of epidural fat?" European Spine Journal, vol. 17, no. 10, pp. 1324-1328, 2008.

[122] R. Sinha and S. Kapoor, "Gender difference in fat indices as evident in two generations," Anthropologischer Anzeiger, vol. 67, no. 2, pp. 153-163, 2009.

[123] J. C. K. Wells, "Sexual dimorphism in body composition across human populations: associations with climate and proxies for short- and long-term energy supply," American Journal of Human Biology, vol. 24, no. 4, pp. 411-419, 2012.
[124] H. MacPherson and A. Asghar, "Acupuncture needle sensations associated with De Qi: a classification based on experts' ratings," Journal of Alternative and Complementary Medicine, vol. 12, no. 7, pp. 633-637, 2006.

[125] A. Y. Leung, J. Park, G. Schulteis, J.-R. Duann, and T. Yaksh, "The electrophysiology of De Qi sensations," Journal of Alternative and Complementary Medicine, vol. 12, no. 8, pp. 743-750, 2006.

[126] C. C. Gunn and W. E. Milbrandt, "The neurological mechanism of needle-grasp in acupuncture," American Journal of Acupuncture, vol. 5, no. 2, pp. 115-120, 1977.

[127] H. M. Langevin, D. L. Churchill, J. R. Fox, G. J. Badger, B. S. Garra, and M. H. Krag, "Biomechanical response to acupuncture needling in humans," Journal of Applied Physiology, vol. 91, no. 6, pp. 2471-2478, 2001.

[128] J. G. Lin, "Evaluation of the depth of de-qi for various acupuncture loci on human thorax and correlation between de-qi and electric resistance," Zhong Xi Yi Jie He Za Zhi, vol. 11, no. 10, pp. 628-630, 1991.

[129] W. Cai, "Acupuncture and the nervous system," American Journal of Chinese Medicine, vol. 20, no. 3-4, pp. 331-337, 1992.

[130] J. G. Lin, Review on the history and practice of the needling depth of acupoints [M.S. thesis], National Research Institute of Chinese Medicine, Taipei, Taiwan, 2011.

[131] S.-R. Huang, Q.-X. Lin, J. Tang, and J.-C. Chen, "Study on the needling depth of point Yaotu with CT scanning," Zhongguo Zhen Jiu, vol. 26, no. 9, pp. 635-638, 2006.

[132] Y. X. Sun, Q. F. Wang, and J. Zhang, "On the needling depth of filiform needle at acupoints," Zhongguo Zhen Jiu, vol. 25, no. 3, pp. 203-206, 2005. 


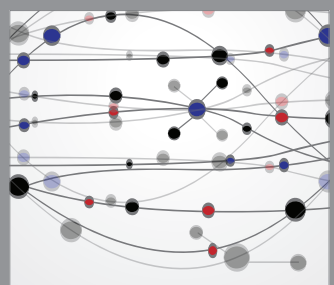

The Scientific World Journal
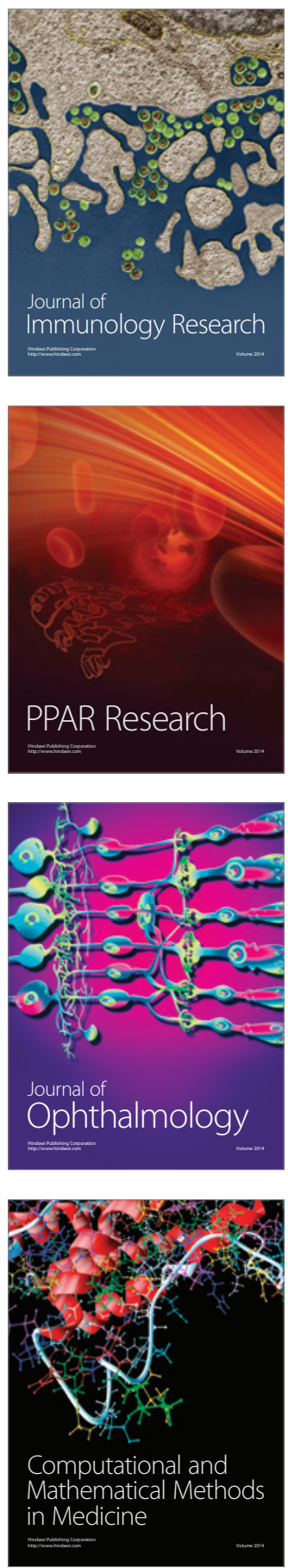

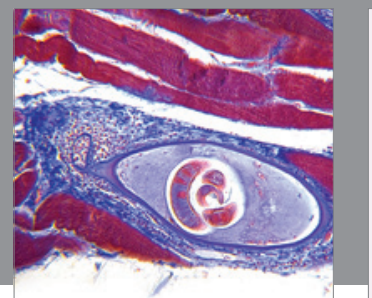

Gastroenterology

Research and Practice
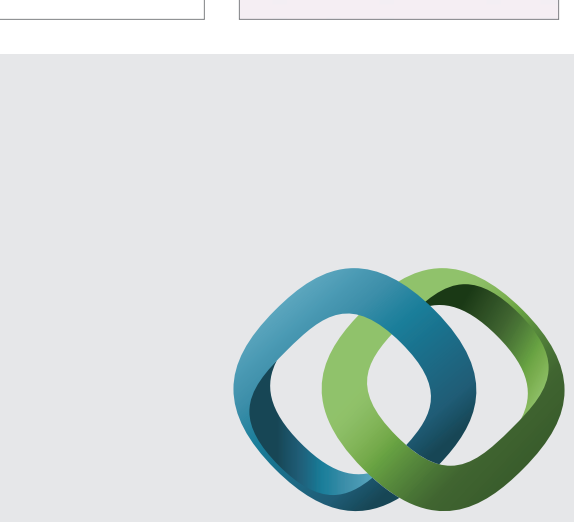

\section{Hindawi}

Submit your manuscripts at

http://www.hindawi.com
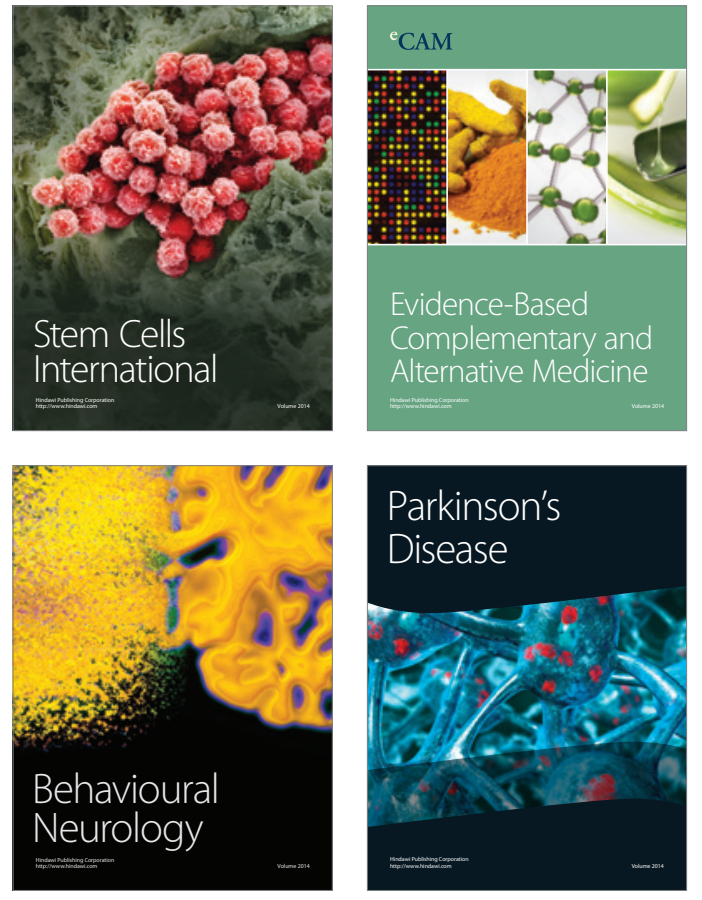
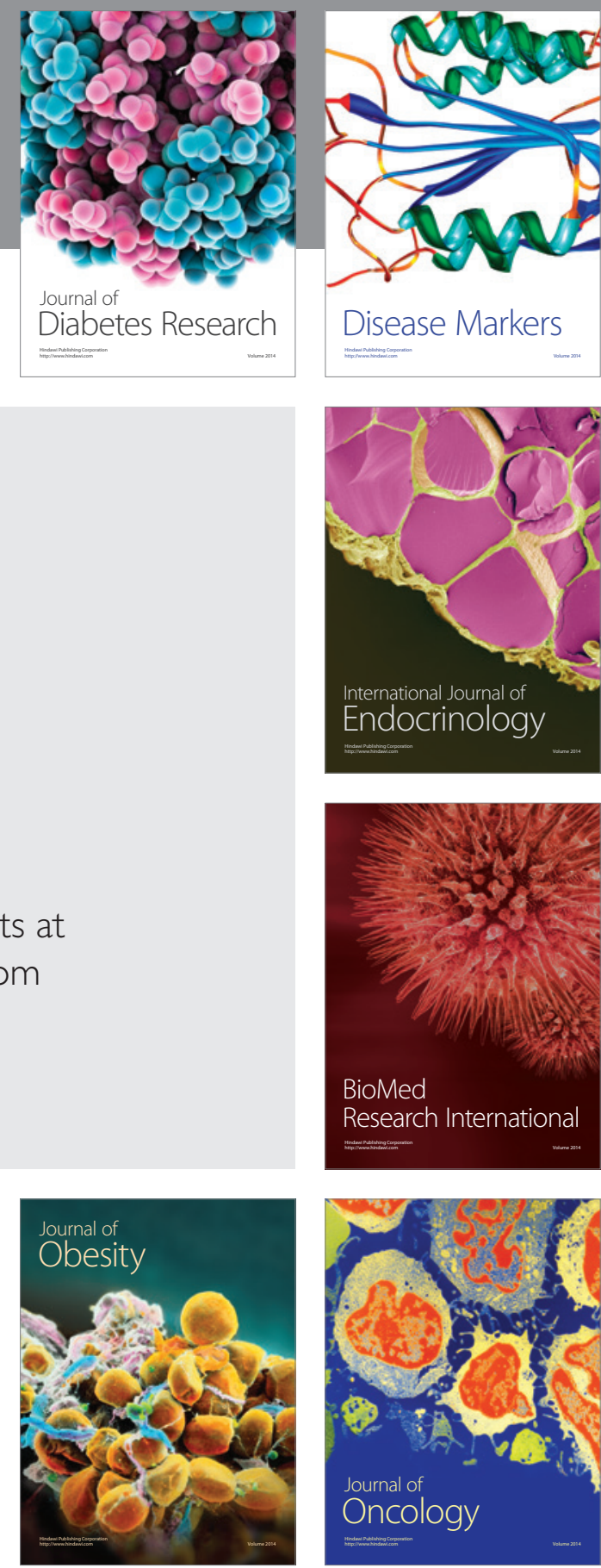

Disease Markers
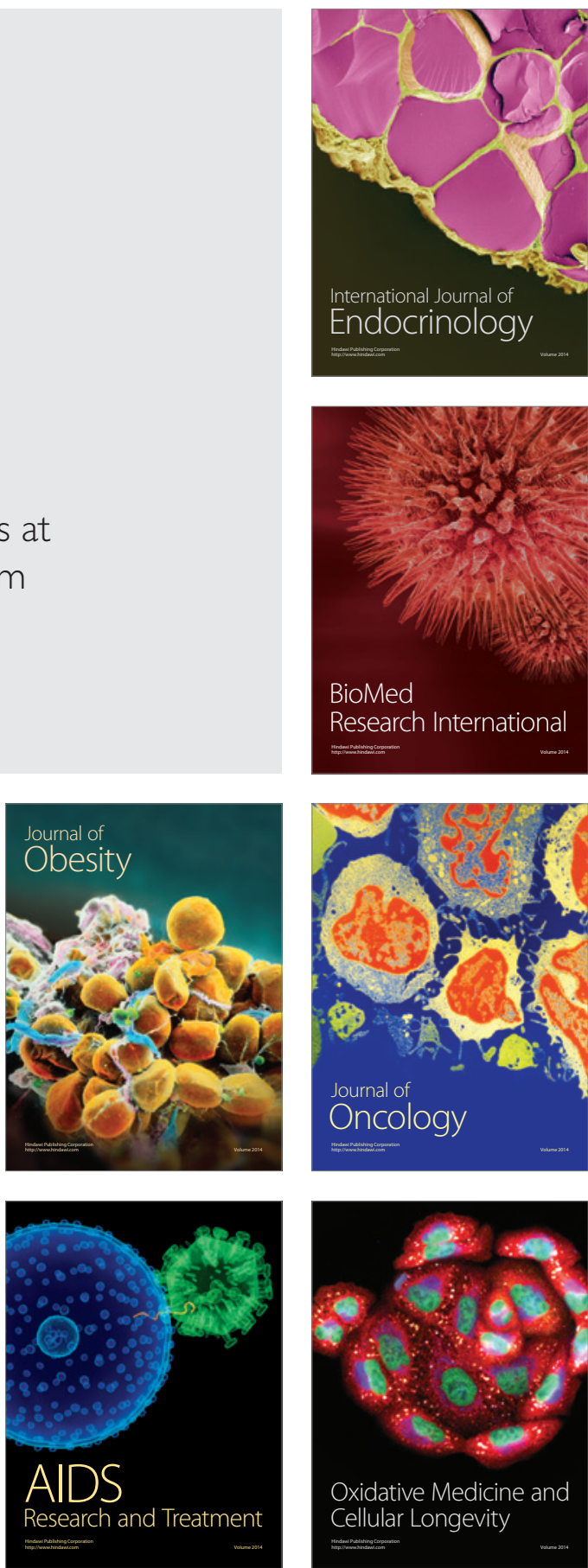